City University of New York (CUNY) CUNY Academic Works

6-2017

\title{
The Economics of American Higher Education
}

Robin Freedman

The Graduate Center, City University of New York

\section{How does access to this work benefit you? Let us know!}

More information about this work at: https://academicworks.cuny.edu/gc_etds/2081

Discover additional works at: https://academicworks.cuny.edu

This work is made publicly available by the City University of New York (CUNY).

Contact: AcademicWorks@cuny.edu 


\section{THE ECONOMICS OF AMERICAN HIGHER EDUCATION}

by

ROBIN FREEDMAN

A master's thesis submitted to the Graduate Faculty in Liberal Studies in partial fulfillment of the requirements for the degree of Master of Arts, The City University of New York 
(C) 2017

ROBIN FREEDMAN

All Rights Reserved 
The Economics of American Higher Education

by

\section{Robin Freedman}

This manuscript has been read and accepted for the Graduate Faculty in Liberal Studies in satisfaction of the thesis requirement for the degree of Master of Arts.

Date

Date

Elizabeth Macaulay-Lewis

Executive Officer
Anthony G. Picciano

Thesis Advisor 


\author{
Abstract \\ The Economics of American Higher Education \\ by \\ Robin Freedman
}

Advisor: Anthony G. Picciano

American higher education is facing a perfect storm of converging issues and challenges which are threatening the demand for its product and the value proposition it offers. Many of these challenges, such as changing delivery models, rising student debt, lower government funding, growing economic inequality and job readiness concerns are all potential obstacles to a college degree, which continues to command a wage premium in the job market. Using a literature review methodology to examine the body of material that is available on this topic, a synthesis of current thought was created. This examination included a review of Moody's Investors Service credit outlooks for the sector in the post-Recession period (2012-present) to determine if Moody's outlook aligns with current higher education thought leaders. The results showed a consensus of thought on the need for continued improvement of the cost and quality of the educational delivery model, which will address the issues of affordability, educational attainment, productivity, job readiness, and globalization. This improvement requires not only a monetary investment in technological innovation but faculty and executive leadership support to achieve economic stability and sustainability for American higher education. 


\section{Preface}

Higher education in the United States impacts virtually every facet of our society and, with the ever-increasing focus on a knowledge-based economy, has become even more essential to the productivity of our lives. Clark Kerr, former Chancellor of the University of California, referenced the role of knowledge in 1963, shortly after Peter Drucker, in 1959, coined the phrase "knowledge worker". ${ }^{1}$ Kerr states:

The basic reality, for the university, is the widespread recognition that new knowledge is the most important factor in economic and social growth. We are just now perceiving that the university's invisible product, knowledge, may be the most powerful single element, in our culture, affecting the rise and fall of professions and even of social classes, of regions and even of nations. (Kerr, 2001, p. xii)

As such, higher education is in the midst of a lively debate about what direction it needs to take to meet all of the challenges it is facing in a rapidly changing world. This lively debate bears a striking likeness to the 2016 Presidential election, with its call for a "change candidate" dominating the discussion.

With the country clamoring for change, the election demonstrated that the idea of change meant different things to different people, as evidenced by how campaign rhetoric was received by the American public. Agendas for change seemed universal in their promise to improve the lives of many Americans, but how these messages for change were heard, or not heard, highlights the great disparity of values and viewpoints held by Americans. For some Americans, campaign messages were interpreted as hope for a better America; for others, the same messages

\footnotetext{
${ }^{1}$ It was popularized by Peter Drucker in his 1969 book, The Age of Discontinuity with a chapter named "The Knowledge Economy".
} 
evoked fear of America's demise. The electorate chose to embrace a call for change

characterized by populist rhetoric, which sounded comforting and protective, a return to the past, to a time when things were simpler and, presumably, better. In the final analysis, can that really be called change?

Indeed, Kerr (2001) has been called prescient in warning about the dangers of returning to the past, as he shares his thoughts on the state of the university in 1963: "Instead of platitudes and nostalgic glances backward to what it once was, the university needs a rigorous look at the reality of the world it occupies today." (p. xi)

Agendas for change in higher education abound, and, like the 2016 campaign messages, are evoking both hope and fear amongst its various stakeholders. But just as political movements are re-examining their mission and message, higher education is being forced to do the same. Changes in demographics, affordability, technology, socio-economic mobility, the science of learning and the role of faculty are all happening at once and are challenging the current U.S. higher education model. What is hanging in the balance is an unfulfilled demand for more college graduates with the requisite skills to enter the labor market and fill new jobs, currently on pace for a projected deficit of 5 million graduates by 2020. (Craig, 2015)

Change is the theme for the times we live in, with the Digital Age turning into the Conceptual $\mathrm{Age}^{2}$ and the demand for new skills: the ability to conceptualize and understand abstract relationships, develop ideas, and solve problems creatively in a dynamic environment. As popularized by Daniel Pink's best-selling book, A Whole New Mind: Why Right-Brainers Will Rule the Future, we know that the world is at a turning point—-between a digital age where

\footnotetext{
${ }^{2}$ Higher order thinking and creative problem-solving are the new in-demand skills in the 21 st century, and they rely on our ability to find meaning, to see things that exist outside of raw facts and numbers, to see the beauty and identify meaning in patterns and creatively use our insights to solve problems that cross a variety of different fields. https:/www.diygenius.com/higher-order-thinking/
} 
knowledge, logic and analysis thrived, and a conceptual age where creativity, innovation, and design skills are more strongly valued. (Menon, Teng, Asad \& Pasupathy, 2016)

How society embraces or resists pervasive change is the same challenge facing higher education. How does our society prepare today for the world of tomorrow? How does higher education adapt today in order to graduate students with the skills of tomorrow? Our society and higher education, alike, represents many points of view with different agendas, and charting a course to the future is more complex than ever; one of the pressing issues both face is the changing socio-economic stratification both in our country and around the world.

There has been an increase in economic inequality and a decline in social and economic mobility in the United States. (Craig, 2015) By contrast, the global middle class is experiencing rapid expansion. According to the OECD, the global middle class is projected to grow from 1.8 billion people in 2009 to 3.3 billion by 2020 and 4.8 billion by 2030. (Carey, 2016) How our society and higher education responds to this fundamental economic shift of both our domestic and global populations will be critical in shaping the world order.

Precisely what is necessary, and hoped for, is the capacity for change, and the adeptness to use the skills of the Conceptual Age to craft an outcome that meets the challenges of globalization, technological innovation and economic sustainability in the U.S. higher education sector.

My hope is that this study will provide additional clarity on these issues and advance the discussion toward that end. 


\section{Table of Contents}

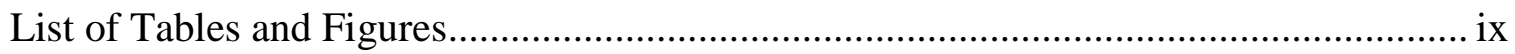

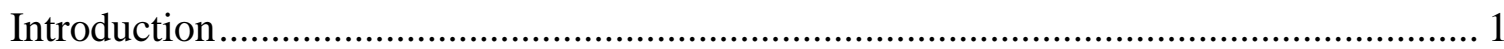

The History of American Higher Education .......................................................... 6

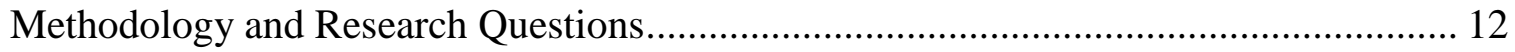

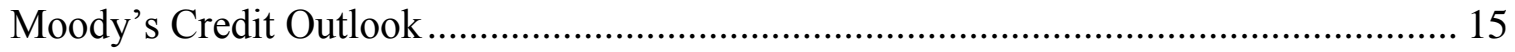

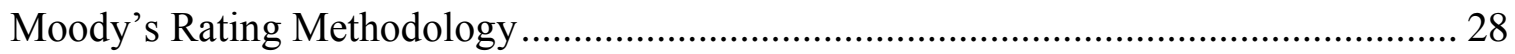

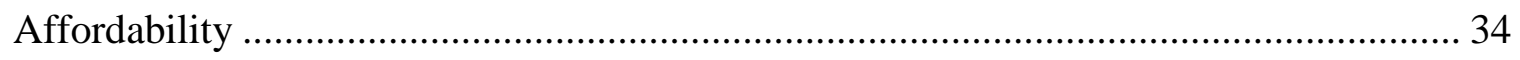

Economic Theory, Income Inequality and Higher Education .................................... 39

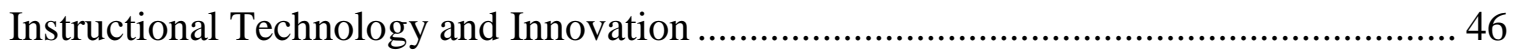

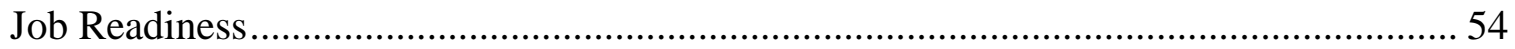

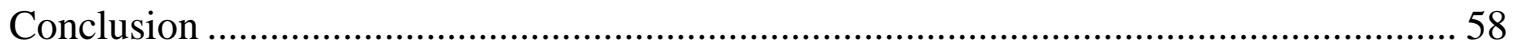

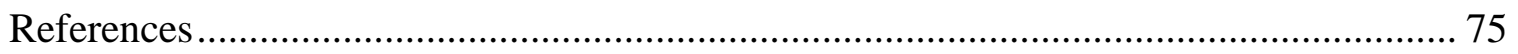




\section{List of Tables and Figures}

Table 1-Moody's Credit Ratings and Definitions......................................65

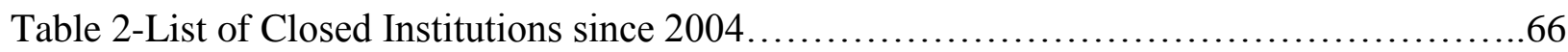

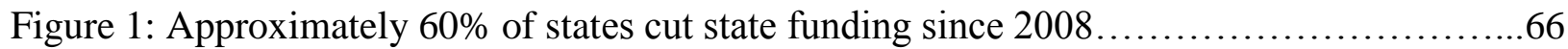

Figure 2: State spending per FTE student.......................................67

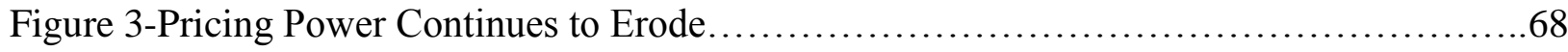

Figure 4-Growth of Net Tuition per Student........................................68

Figure 5- Sector-Wide Public Revenues are Diversified...............................69

Figure 6- Sector-Wide Private Revenues are Diversified................................69

Figure 7-College Wage Premium............................................... 70

Figure 8-Aggregate Income By Quintile.......................................... 71

Figure 9-Income Distribution By Quintile............................................72 
Introduction

The resiliency of American higher education is being tested with the looming prospect of the "bursting of the College Bubble" (Sykes, 2016, p.7), a reference to the housing bubble of a decade ago. That bubble led to the subsequent collapse of the housing market which triggered the Great Recession in 2008. Big banks and other financial institutions who had taken on excessive housing-related mortgage and investment risks incurred severe losses and either faltered or failed. This, in turn, caused massive job layoffs, first in the financial sector, and then other industry sectors. What resulted was a steep and rapid increase in unemployment and the enormous economic downturn we are still recovering from today, almost a decade later.

How did higher education fare during the Great Recession? Higher education experienced its own "perfect storm", which resulted in financial instability for a significant number of colleges and universities who found themselves extremely vulnerable as the economy struggled. Conventional wisdom in higher education had been to follow the "Law of More" (Jason, 2016) and to raise tuition to finance the "More", hoping to improve their rankings and reputation.

The perfect storm arrived when colleges and universities, needing to continue to increase tuition to cover their increased spending, were forced to offer increased financial aid and deep discounts as consumers were struggling financially and were unable to afford rising tuition costs. A closer look shows that average tuition at American colleges shot up from 23.2 percent of median annual household earnings in 2001 to 37.7 percent in 2010 . That rate of increase is $61 / 2$ times the rate of inflation. (Jason, 2016) 
Public universities were dealing with the additional pressure of significant declines in state funding, despite increased enrollments, during the Great Recession (See Figure 1). Other state funding essentials such as Medicaid and pension costs compete with higher education for state funding. One in ten state dollars went to Medicaid in 1987, according to the National Association of State Budget Officers. In 2012, close to one in four dollars did. (Hebel, 2014) By 2014, 25.6 percent of state spending from total state budgets funded Medicaid. (MACPAC, 2017) The $\$ 11,000$ spend per student in 2012 , according to the State Higher Education Executive Officers, was almost exactly the same, when inflation is taken into account, as they spent a generation ago. (Figure 2) Given a more expensive operating model that includes funding enhanced student amenities and greater technology expenditures, there was clearly more financial pressure on public institutions than ever before to meet this economic challenge.

Higher education struggled financially through the Great Recession. Although the circumstances called for financial restraint, private, not-for-profit colleges and universities remained focused on expansion (Law of More) and upgrading of amenities to attract students and remain competitive in the college marketplace. As such, they turned increasingly to borrowing through banks and public debt to finance this expansion and upgrading of facilities, which put increased financial pressure on them and resulted in greater financial instability for these institutions. Jeff Denneen and Tom Dretler of Bain \& Company comment on this in their 2012 report, The Financially Sustainable University:

Much of the liquidity crisis facing higher education comes from having succumbed to the "Law of More." Many institutions have operated under the assumption that the more they build, spend, diversify and expand, the more they will persist and prosper. But instead, the opposite has happened: Institutions have become overleveraged. Their long-term 
debt is increasing at an average rate of approximately $12 \%$ per year, and their average annual interest expense is growing at almost twice the rate of their instruction-related expense. In addition to growing debt, administrative and student services costs are growing faster than instructional costs. (Denneen \& Dretler, 2012)

Hence, at the same time that private, not-for-profit colleges and universities were pressured to discount tuition revenue, they continued to raise the full price of tuition to offset the discounts (resulting in weak net tuition revenue growth) in an attempt to cover their expenses, including rising interest costs on their increasing debt. By 2012, after a decade of unprecedented spending, debt levels had more than doubled at over five hundred colleges and universities rated by the credit agency Moody's Investor Services. This led to the downgrading of the credit ratings of more than three dozen of these institutions. (Sykes, 2016) These downgrades reflected poorly on these institutions' reputations and viability, which had adverse effects on their ability to attract new students, faculty, and alumni willing to donate. Further, lower credit ratings compounded their financial struggles by making it more expensive and more difficult to secure additional borrowings.

As Moody's ratings downgrades of colleges and universities continued, a great deal of concern and discussion was generated in the higher education community and beyond. The collective concern peaked when the overall higher education sector was given a negative outlook by Moody's in July 2014. This negative forecast for the sector occurred as many small private colleges found themselves in serious financial trouble; during the years 2010-2014 there were 29 college closings, predominantly small, four year, not-for-profit colleges. (Jacobs, 2015)

Many other factors across the entire sector played a part in the financial crisis experienced in higher education, and many of these factors continue to plague the sector: the 
ongoing economic impacts of changing demographics, alternative delivery models, rising student debt, lower government funding, growing economic inequality and job readiness concerns. Each of these factors has the ability to dramatically impact the demand for higher education and how society values it.

An ongoing discussion of these and other factors is occurring among educators, legislators and consumers, with the goal of determining how much and where American society is willing to invest in higher education to allow for the desired and maximum return on investment: maximum degree completion rates and maximum career outcomes. This has initiated an active discussion on how to share the costs equitably and how to direct the resources where they are most needed. (Bowen \& McPherson, 2016)

The value of a college degree is being closely examined as there is a growing disconnect between the investment in a college degree, which includes taking on student loans, and the return on investment. While the average student debt load rose $24 \%$ in the last decade, average wages for graduates aged 25-34 fell by $15 \%$. This is corroborated by the fact that at least $40 \%$, and as much as $63 \%$ of recent graduates are working in jobs that do not require a college degree, presumably resulting in lower wages. These statistics support the findings of a survey of 30,000 alumni by Gallup-Purdue Index that only $38 \%$ of recent college graduates "strongly agree" that their degree is worth the cost. (Sykes, 2016) Moody's has weighed in with warnings of worsening performance of student loans, further evidence that the "underlying asset", in this case, the value of a college degree, is in great question. As Sykes (2016) notes, "Bubbles burst when buyers realize that the value of the asset is not worth the inflated price." (p.14) Economic analyst and Forbes contributor Jesse Colombo warns that when this bubble bursts, "the higher 
education industry will have no other choice but to drastically downsize until it is much smaller than its current size." (Sykes, 2016, p. 16)

Moody's Investors Service has followed the higher education sector closely and provided incisive analyses throughout these post-Recession years. In many ways, their credit research has served as a bellwether for the sector. Their outlooks for the sector from 2012-2016 showed slow improvement, from negative to stable; but the recently released 2017 Outlook is titled "Stable with Clouds Forming on the Horizon", clearly a cautionary tale.

Not surprisingly, the clouds that are forming are the result of the ongoing challenges that higher education is currently facing: weak tuition revenue growth, rising inflation and labor costs, anticipated funding declines and the call to adopt technological innovation. An in-depth review of these factors and their related impacts is necessary to determine how higher education can best respond in order to adapt to a rapidly changing, technology-driven world and sustain the quality and reputation that the public has come to expect.

To carefully examine the issues and challenges that American higher education faces today, it will be useful to review and understand the history of America higher education, which follows. 
The History of American Higher Education

The roots of American higher education can be traced back to Europe. The first modern university was created in Bologna in 1088, where students came together in the pursuit of knowledge, hired teachers and directed them in their duties. The next major European university was established in Paris in the mid-twelfth century and the faculty, previously from the cathedral school at Notre Dame, organized themselves by discipline. (Carey, 2016) In 1167, English students, who were forbidden by Henry II to attend the University of Paris, were joined in Oxford by masters (teachers) and began learning. Residential housing was built and several colleges were formally created and became part of the Oxford University colleges. Cambridge University was established soon after, also following the residential college example. (Carey, 2016)

The first American university was modeled after Cambridge, and named for a Cambridge graduate, John Harvard, who died and left the college a sizable sum of money and his personal collection of books. The college was named after him in 1639. By 1776, there were a total of nine colonial colleges, all molded after the British residential college profile. States were free to allow, and encouraged, the creation of new colleges and by the start of the Civil War, there were approximately 250 colleges and universities across the country. (Carey, 2016)

During the post-Enlightenment period, in 1809, a German linguist and philosopher, Frederick Wilhelm von Humboldt, started a new university in Berlin focused on philosophy and science, graduate instruction and research. American scholars, who observed this university firsthand, supported the idea of a research university and founded Johns Hopkins University in 
1876. Its mission was to "provide advanced instruction, not professional, to properly qualified students in various departments of literature and science" (Carey, 2016, p. 27) as the first American research university of its kind.

During the previous decade, the Morrill Land-Grant Act was signed in 1862, establishing public universities on federally provided tracts of land. This land grant movement provided training and education in the agricultural and engineering disciplines to a wide range of children of farmers and workers. Along with the research university, they "served an industrialized nation and they both did it through research and the training of technical competence." (Kerr, 2001)

The modern university that emerged was called the "multiversity" by Clark Kerr, former Chancellor and Professor at the University of California, Berkley. The multiversity grew to have many parts, to serve a growing and diverse community of interests and endeavors, "a mechanism held together by administrative rules and powered by money." (Kerr, 2001, p. 15) Kerr described a multiversity as multiple communities-undergraduates, graduate students, humanists, social scientists, scientists, professional schools, nonacademic personnel, administrators as well as others related to these internal communities-alumni, legislators, farmers and businessmen. (Kerr, 2001) This model combined liberal arts colleges, professional schools and graduate schools where research and teaching were synergistic.

The next transformation in U.S. higher education took place in 1945, at the end of World War II, when the federal government partnered with universities to fund scientific research. This scientific revolution, coming after the Industrial Revolution, created what Clark Kerr called "the federal grant university." This initiative was led by Vannevar Bush, then Director of the Office of Scientific Research and Development, who sent a report to President Truman calling for the 
federal government to fund scientific research grants through the National Institutes of Health and the predecessor to the National Science Foundation. Thus began the Golden Age for research universities, with funding growing from $\$ 310$ million in 1940 to almost $\$ 7$ billion by 1990. (Kerr, 2001)

Along with the rapid expansion of the research university, came the passage of the GI Bill in 1944, which provided returning servicemen with money to pay for college and a major stimulus to mass higher education in the United States. Two million veterans enrolled in colleges nationwide by 1950. (Carey, 2016)

American universities were considered the finest in the world in the second half of the twentieth century. The "multiversity" grew to a size and scope that allowed interaction among large groups of diverse researchers, and with decentralized control, offered tremendous competition between public and private institutions. The enrollment in higher education in the United States grew at enormous rates. Goldin and Katz (2008) noted:

Whereas $10 \%$ of all Americans born in 1900 would attend some college, $50 \%$ of those born in 1950 did. About 4\% of all Americans born in 1900 would graduate from a fouryear college, but $24 \%$ did among those born in 1950. (p. 283)

After World War II, the middle class continued to grow and legal rights expanded for minorities and women to make colleges more inclusive. With this backdrop, in 1960, Clark Kerr created the California Master Plan for Higher Education, which created a three-tiered hierarchy of institutions to create a place in higher education for every person. The top tier was the University system, enrolling the most qualified students and conducting research. The middle tier would be the State system, emphasizing more teaching and less research and following the land-grant model which educates teachers and other middle-class professionals. 
The last tier would be the community colleges that would be available to everyone and least expensive. (Carey, 2016) Other states instituted a similar expansion plan and, in 1965, the federal government stepped in to do its part, as President Johnson signed the Higher Education Act which authorized subsidized student loans to help students pay for college. With college enrollments projected to decline, and the threat of college and university closings, the 1972 reauthorization made college more affordable and transformed the funding of higher education by creating Pell Grants, need- based vouchers to pay for college. This program, along with subsidized loans created, what Robert Zemsky (2013) called, a "federalized market with little incentive to change.” (pp. 41-43)

The numbers would bear this out. Pell Grants grew from \$234 million in 1973 to about $\$ 35$ billion by 2010 , with the number of students receiving grants increasing from less than 2 million to more than 9 million. Federal student loans increased from $\$ 7.3$ billion to $\$ 104$ billion over the same period. By 2010, one-third of undergraduate students had taken out a Stafford student loan. Loans replaced savings for the middle class, as almost half of students from families with incomes over $\$ 92,000$ took out federal loans, along with $80 \%$ of students from families earning $\$ 92,000$ or less. (Zemsky, 2013)

Clark Kerr saw higher education entering, what he called, the Great Academic Depression, by 1980. What did he mean? The expansion of new colleges and universities had ended. The research university or hybrid university, as Kevin Carey refers to it, started to show its flaws. Colleges began competing with each other just as the U.S. News \& World Report started ranking colleges and universities in 1983. The "arms race" began as institutions started competing for a finite pool of qualified students by increased spending on amenities and athletics to attract these students, driving up their costs and ultimately, tuition. The college wage 
premium remained strong as the highly skilled worker was in high demand. College attainment rates, however, did not keep up with demand; Goldin and Katz cite slowdown in growth of educational attainment as the single most important factor causing the college wage premium since 1980, and a major contributor to family income inequality. (Goldin \& Katz, 2008) Educators like Robert Zemsky called for curriculum changes in the 1980s to simplify and streamline course offerings in order to increase graduation rates and reduce time-to-degree and operating costs; but he was met with resistance and a clear message that faculty's desire was to preserve the status quo.

Clark Kerr (2001) called the period from 1990-2015 (projected in 2001) the age of constrained resources. State funding, which had grown dramatically in the 1960's and peaked in the mid-1970s, began its precipitous decline of almost 40 percent from the mid-1970's to 2010 (Archibald \& Feldman, 2011). By the mid-1990's, foundations which had supported higher education research and other initiatives began shifting their giving to non-profits interested in addressing affordability and completion rates. (Zemsky, 2013) A 2012 Gates Foundation video highlights the growing concern about the future of higher education:

By 2018, 63 percent of all American jobs will require some sort of education beyond high school. In real numbers that means American employers will need 22 million workers with postsecondary degrees. But research shows that if we don't do something about this problem, we'll fall short by 3 million graduates. The future of our young people and our country is at stake. We must educate our way to a better future. (Carey, 2016) For-profit higher education, even with its checkered past, is creating an alternative pathway to a degree that is lower-cost and yielding higher graduation rates. They are reaching out to the non-traditional student, including the working and disadvantaged student, and offering 
flexible, online options. After reaching a peak in 2010, enrollment at private, for-profit institutions decreased by 26 percent (from 1.7 million to 1.3 million students) between 2010 and 2014, representing 7.5 percent of the total college enrollment for 2014. (U.S. DOE, 2016)

Clark Kerr (2001) had a clear vision of higher education and what the future would look like when he delivered a series of talks at the Godkin Lectures at Harvard in 1963. He, himself, admits he was quite prescient at that time, as he spoke proudly of the Golden Age of Higher Education and highlighted its greatest impacts on higher education: universal access, federal funding of scientific research and the enhanced availability of resources. His 2001 essay is far less clear, as he then stated:

I wish that today, however, I might again be so prescient about the shape of things to come, but I cannot...I think having a clear view of the future is now much more difficult, perhaps impossible. We live in an age of too many discontinuities, too many variables, too many uncertainties, as almost any university president today can certify. (p.201) This sentiment has endured, as higher education continues to write its history and deals with discontinuities and uncertainties, but finds itself changing as the world around it does. Calls for change from educators, students, legislators, administrators and employers are being heard and, as conveyed frequently in the literature, change is messy, not usually planned and orderly; but somehow change follows emergent trends and, often through the collective effort of various stakeholders, higher education finds itself changed.

The research questions for this study, and the methodology that will be employed to explore and answer these questions, will follow. 


\section{Methodology and Research Questions}

The proliferation of published materials on the topic of change and transformation in American higher education strongly suggests that a literature review, as a methodology, would be an effective way to review the body of work that is currently available on this topic, and create a synthesis of current thought as it relates to relevant research questions.

Michael Bassis, Senior Fellow, Association of American Colleges and Universities, acknowledged the importance of keeping up with current thought in his 2015 study, A Primer on The Transformation of Higher Education in America, that:

As the pace of change has accelerated, the future of higher education has become more unpredictable and discussions about how to maintain its relevance to the American dream intensified. The amount of published material on the topic grows larger each year. As a consequence, all but the most conscientious observers, including most faculty, administrators, trustees and policy makers, are likely to have gaps in their understanding of the problems that need attention, the range of initiatives now underway to address these problems and the likely consequences of adopting or failing to adopt one or another policy or initiative. To the extent that is true, their perceptions about and their attitudes toward the changes that are unfolding in higher education today may not be well informed, making it difficult for them to participate effectively in the ongoing dialogue. (p.3)

John Creswell (2014), a professor of Educational Psychology who specializes in research design, cites various types of appropriate literature reviews that would "(a) integrate what others 
have done and said, (b) criticize previous scholarly works, (c) build bridges between related topics, and (d) identify the central issues in a field." (p. 61)

This study attempts to examine how American higher education, after the Great Recession, can become economically sustainable and continue to offer an affordable, quality product. The basic assumptions in this study are:

1. Lack of affordability accelerated during the Great Recession and has greatly impacted the demand for higher education and how society values it.

2. Student debt burden increased dramatically as a result of reduced government funding and rising tuition prices after the Great Recession.

3. The current higher education delivery model has been slow to change and is feeling pressure to embrace technological innovations and new modes of learning.

4. Moody's Investors Service rates colleges and universities according to how effectively they grow tuition revenue, manage spending and deal with adversity and change.

The first assumption, affordability, has many facets, which will be examined, including economic inequality, economic productivity and government funding. These factors are complex and, in most cases, also interrelated.

The second assumption confirms the need to determine who should pay for higher education as the price of tuition continues to rise, along with student debt, while government aid is declining.

The third assumption has also fueled an active discussion inside and outside of higher education. The current opinions and research findings of thought leaders calling for changes to the higher education delivery model will be reviewed and, synthesized with the analysis 
and discussion of the first two assumptions, to form a vision for an overall higher education model that will be economically sustainable, produce significantly improved graduation rates and the skills needed to fuel the economic engine of the U.S. and global economies.

Based on the above assumptions, the major questions in this study are:

1) How should American higher education address the challenges that are impacting the demand for its product, specifically:

a) What changes should be made to the delivery model to embrace pedagogical innovations?

b) What changes should be made to improve graduation rates and job placement outcomes which will ensure an adequate return on college investment?

c) How will the challenges of affordability, funding and student debt be addressed?

2) How well did Moody's identify the risks and areas of concern during and after the Great Recession and did it impact the direction higher education has taken?

The ultimate question becomes:

What changes will American higher education need to make to deliver the value proposition that will attract and graduate the maximum number of students, while maintaining economically sound institutions that are in sync with Moody's rating criteria for the sector? A detailed review of Moody's Credit Outlook for the sector in the years following the Great Recession (2012 to present) is a good launching point for this analysis. 


\section{Moody's Credit Outlook}

Throughout the Great Recession and post-recessionary period, the higher education sector would look to the credit markets for additional funding. Even with significant efforts to control costs, colleges and universities experienced weak tuition revenue and decreased government funding, and needed to increase and rely on their borrowings to fund expansion as well as day-to-day operations. As a result, Moody's Investors Service, which performs examinations of colleges and universities to determine their creditworthiness, weighed in on the financial health of those institutions that were attempting to raise money through issuing bonds in the public credit markets. In total, they rate over 230 public universities and more than 280 private colleges, along with almost 70 community colleges. Moody's credit review results in an assigned rating that is based on a detailed analysis of all aspects of operations of an institution, and they also provide annual outlooks for the sector as a whole.

With the financial picture worsening during 2012, Moody's gave the entire U.S. higher education sector a negative outlook for its 2013 rating. This came after 22 colleges had their credit ratings downgraded in 2012. The number one factor contributing to the 2013 negative outlook was that price sensitivity continued to suppress net tuition revenue growth. All but the most elite universities faced diminished student demand and increased price sensitivity due to a prolonged period of depressed family income and household net worth (Bogarty, Behr, Kedem \& Nelson, 2013), and a dip in the number of domestic high school graduates since the peak of 3.34 million for the school year 2007-08. (Prescott, 2012) In addition, there was concern regarding negative accreditation actions, which increased by almost 50\% from 2009 through 2011. (Bogarty, Behr, Kedem \& Nelson, 2013) 
This outlook shift, from stable to negative, sent a shock wave through the higher education sector and evoked responses, such as the one from Vassar President, Catharine Bond Hill, who weighed in on the matter, as a former economist, in February of 2013. Hill felt that the rating did not take into account whether the risks facing higher education were permanent or temporary, which would determine the appropriate response by the sector. She cited the stagnation in income growth in the United States, as well as the uneven distribution of income across families, as a primary factor in the negative outlook on tuition. Hill asserted that the ability to raise tuition would be determined by the return of income growth, presumably making this a temporary problem. She cited reduced public funding as a permanent challenge, unless priorities at the state and federal levels change. On the other hand, Hill viewed the weak financial market returns as cyclical and not a long term trend. Lastly, she conceded that overspending in the boom years preceding the recession should have been tempered, but that Moody's offered little evidence to support any of these concerns as long term trends to be reckoned with. Finally, Hill emphasized that "higher education is incredibly important to the future prospects of the United States." (Hill, 2013)

As 2013 proceeded, Moody's warned that "negative ratings pressures have intensified on higher education." They downgraded 21 public colleges and universities and upgraded none. Among the private schools, there were 13 downgrades and 9 upgrades. Moody's cited overall "declining state funding, flat or declining enrollment and lack of expense containment." (Rivard, 2013)

While colleges and universities continued to address the challenges of the perfect storm in 2013, macroeconomic pressures, including continued higher unemployment and income stagnation, were still suppressing the growth of net tuition revenues. Moody's cited this when 
they issued their continued negative 2014 outlook in November 2013. They cited "continued price resistance and a challenged federal budget leading to weak revenue growth" coupled with the pressure to increase expenses "to invest in programs and facilities [which] will result in deterioration of financial performance.” (Bogarty, Kedem, Behr, Fitzgerald \& Smith, 2013)

The 2014 outlook weighed in on the increased competition from online delivery models. The report stated that "over the next several years, navigating this landscape will have economic impacts (both positive and negative) and... force institutions to become more nimble in their strategic positioning." Specifically cited were "increased cross-registration in online courses, growing focus on competency based models, and moves to unbundling of educational services potentially increasing mobility across institutions." Moody's would continue to monitor how institutions respond strategically to these challenges. They felt that over the long term, the greater access and flexibility to students and the reduced cost yielded by collaboration among institutions offering online courses will be credit positive. Similarly positive, they cited cost efficiencies to be achieved through mergers, partnerships and shared services within a university system. They viewed tenure and unionization as obstacles for cost efficiencies. (Bogarty, Kedem, Behr, Fitzgerald \& Smith, 2013)

Notwithstanding these challenges, Moody's highlighted the continued strength of the value proposition of higher education. This is evidenced by the correlation between higher income and college attainment, with U.S. Census Data showing that a bachelor's degree holder earns $60 \%$ more than a high school graduate. Endowments showed increased returns in 2013, with a return of $12.2 \%$ among Moody's rated institutions. Fundraising also increased as a result of stock market strength. (Bogarty, Kedem, Behr, Fitzgerald \& Smith, 2013) 
Governmental funding for higher education was steeped in uncertainty when the 2014 outlook was published. While Moody's outlook cited possible reductions in the maximum annual Pell Grant award, subsequent legislation increased (from the prior year) the maximum amount college students could receive for the $2014-15$ financial aid award year by $\$ 85$, to $\$ 5730$. For the 2015-16 award year (July 1, 2015, to June 30, 2016), the maximum award is $\$ 5,775$. For subsequent years the maximum award is $\$ 5,815$ for the 2016-17 award year (July 1, 2016, to June 30, 2017) and for the 2017-18 award year (July 1, 2017, to June 30, 2018), the maximum award will be $\$ 5,920$. (U.S. DOE, 2017) According to a government tally, nearly $\$ 32$ billion in Pell Grants were awarded to 9,194,377 students during the 2012-13 financial aid award year, yielding an average per student of $\$ 3,477$. (Lindstrom, 2014) Even so, the maximum Pell Grant covered just $63 \%$ of average public four-year tuition and fees in 2013-14 compared to $87 \% 10$ years ago. (Baum \& Payea, 2013)

Federal research funding was restored through legislation after the 2014 Moody's outlook was published. The bill provided \$29.9 billion for the National Institutes of Health (NIH) in FY 2014. This is a \$1 billion (3.5 percent) increase over the FY 2013 budget after sequestration and transfers, but is \$714 million below the FY 2013 pre-sequestration appropriation, which was $\$ 30.6$ billion. A summary from the Senate Appropriations Committee stated the $\$ 1$ billion increase "should allow the NIH to continue all current research programs and begin approximately 385 additional research studies and trials." (American Society of Hematology, 2014) FY 2015 saw a $\$ 150$ million increase, a mere $0.5 \%$ boost over the $\$ 29.9$ billion it received the prior year. (Kaiser, 2014) The 2016 NIH federal funded budget was $\$ 31.4$ billion. (U.S. DHHS, 2017) The National Science Foundation's FY 2014 budget was set at nearly $\$ 7.2$ billion, an increase of $\$ 287$ million over the prior year, but it left the agency’s 
funding about $\$ 69$ million lower than it was before sequestration. (Stratford, 2014) It received an increase of 2.4\% increase, to \$7.344 billion in FY 2015. (Mervis, 2014) NSF's FY 2016 budget request was $\$ 7.724$ billion, an increase of $\$ 379.34$ million (5.2 percent). (NSF, 2016) These appropriations should be viewed as positives, as Moody's cites that "federal research funding represents approximately $70 \%$ of research grants and contract revenue for their rated colleges and universities and institutes...” (Bogarty, Kedem, Behr, Fitzgerald \& Smith, 2013) Moody's summarized their 2014 outlook conclusions as follows: Net tuition revenue will continue to be stressed and cash flow will decline as colleges begin to increase expenses to stay competitive and viable. Evolving trends that would continue to pose specific challenges to the sector include the continuing growth of online education, the globalization of higher education which would result in increased competition for students, and declines in enrollment, due to declining numbers of high school students for the next several years. Growth was expected to remain depressed until 2016, particularly in the Northeast and Midwest. (Bogarty, Kedem, Behr, Fitzgerald \& Smith, 2013) Public institutions would be competing for out-of-state students, including those outside the U.S., to bolster tuition revenue.

As 2014 unfolded, although the economy continued to improve, Moody's announced in July that the outlook for the U.S. higher education sector continued to be negative. This was mainly due to declining enrollment at over half of all public universities and a net tuition revenue decline at $25 \%$ of regional public institutions for fall 2013 (compared with only $4 \%$ of flagships). Moody's downgraded three dozen four-year colleges and universities since July 2013, with only 9 institutions receiving credit rating upgrades. However, they did see trends emerging that suggested that the sector might be stabilizing over the next 12 months. (Gephardt \& Ortiz, 2014) 
Moody's 2015 outlook, released Dec 2014, remained negative. The report cited slow growth in tuition revenue; the weakest in over a decade (see Figure 3). State appropriations per student remained below fiscal year 2009 levels and increases, for some, were expected to be coupled with state-imposed limitations on tuition increases (see Figure 4). For example, increases in state funding for Ohio public universities came with a requirement to limit fall 2014 tuition increases to no more than $2 \%$. In Florida, a new law eliminated tuition increases pegged to inflation, with many of the state's public universities keeping in-state undergraduate tuition frozen for fall 2014. Public universities' median reliance on government operating support had dipped to new lows, representing less than 25\% of operating revenue in FY 2013, compared to over 30\% in FY 2009.

On a positive note, double-digit average endowment returns in fiscal years 2013 and 2014 aided the majority of universities in growing total cash and investments above prerecession peaks. Because most colleges rely heavily on student charges (75\% median contribution ratio for private universities; $47 \%$ median contribution ratio for four-year public universities), net tuition growth at least at the pace of industry inflation would be necessary for a return to a stable industry sector outlook. Based on Moody's tuition survey in 2014, public institutions were projecting a $1.9 \%$ (compared with $2.7 \%$ at private institutions) increase in net tuition, both below the 3\% required to keep up with inflation.

Fundraising continued to be a distinctive credit strength of the higher education sector, with many universities in the midst of comprehensive fundraising campaigns supporting capital projects, financial aid, faculty and other initiatives. Higher education fundraising was expected to remain strong in 2015 and 2016. Elite, wealthy national private colleges and universities were expected to outperform the rest of the higher education sector over the following 12-18 months 
(2015-2016) because their business models are most closely linked to investment returns and philanthropy, which have been robust in recent years. Further, these institutions benefit from global reputations, deep pools of applicants, revenue diversification and larger endowments supporting expanded financial aid. Their global brands will allow them to command high net tuition per student and will attract the largest gifts. (Tuby, Fitzgerald, Kedem, Behr \& Smith, 2014)

Although the outlook remained negative for 2015, many more signs were pointing in a positive direction. Declining unemployment rates for college graduates, and further data illuminating the lifetime earnings premium for those with a post-secondary education, were credit positive for the higher education sector, and support future growth of enrollment and tuition revenue. Strong enrollment demand from international students presented an opportunity for revenue growth and diversification. Lower student loan default rates were also positive signs for the sector.

These signs led Moody's to revise their outlook to stable from negative in July 2015. The sector's outlook had been negative since January 2013. They projected that net revenue growth would climb to just above 3\% which would provide stability in operating budgets for the first time since 2009. They predicted that state funding should increase above 3\% in FY 2016 coupled with 1-2\% increase in federal research funding. Equity market investment growth contributed to increased gift revenue and endowment spending. Still, they predicted that $20 \%$ of all universities would experience weak or declining revenue growth, greatest at regional public universities and small private institutions. (Bogarty \& Smith, 2015)

This persistent trend of weak or declining revenue growth prompted Moody's to conclude that this trend would continue, as noted in their September 2015 announcement, as 
"Closures and mergers among small US colleges are poised to rise in the next few years amid continued revenue declines, but the overall number will remain low" (below $1 \%$ of the 2300 colleges rated). (Gephardt \& Smith, 2015) Moody’s projected that closures, which averaged five per year 2004-2014, would triple by 2017, and that mergers which averaged two to three, would more than double by 2017. This was consistent with recent research that showed enrollment declines for smaller colleges causing closures and mergers as they struggled to fund their rising fixed costs with falling tuition revenue.

One such research study, Learning from Closed Institutions: Indicators of Risk for Small Private Colleges and Universities authored by two doctoral students, Dawn Lyken-Segosebe and Justin Cole Shepherd at Vanderbilt University, examined the risk factors associated with the closing of many smaller institutions over a ten year period, 2004-2013 (list of institutions at Table 2). The researchers stated that previous literature indicated that low enrollment, low endowment levels, high debt and deferred maintenance were challenges common to small colleges and universities at the time of their closure. (Lyken-Segosebe \& Shepherd, 2013) They looked at institutions that closed with enrollment up to 1000 students and compared them to other thriving institutions of the same size. The closed institutions had higher applications received but slightly lower admissions rates, a higher percentage of part-time students, lower tuition per student $(\$ 9,089$ vs. $\$ 13,973)$, federal contracts and grants less than $40 \%$ of other institutions, and higher tuition dependency (50\% vs. $25 \%$ ). In addition, expenses exceeded total revenues, which caused the schools to fail. The risk profile was summarized as small or declining enrollment at religious and non-degree granting institutions with a high percentage of part-timers, high dependency on tuition as primary source of revenue, and 
significant interest payments on capital projects. This study shed much needed light on the risk factors for closure and brought it to the attention of college and university administrators.

In November 2015, Moody's published the results of their sixth annual tuition survey, "Subdued Net Tuition Revenue Growth is New Normal for US Universities", which revealed that almost two-thirds of public universities projected a median $2.2 \%$ increase in net tuition revenue for FY 2016, a strong indicator that this trend would continue. In addition, the survey found that the median first-year discount rate for private colleges rose to $48 \%$, with $54 \%$ of private universities discounting their "sticker prices" by more than half, reflecting an increasingly competitive market. They also noted that colleges and universities in the South anticipate stronger net tuition revenue growth with an increase in college-age populations while weak population growth will pressure enrollment in the Northeast and Midwest. (Ortiz \& Fitzgerald, 2015)

On December 2, 2015, Moody’s issued their 2016 U.S. higher education outlook and, even though they expected there to be continued pressure on net tuition revenue, they reaffirmed their July 2015 revised outlook as stable, after almost three years of reporting a negative outlook for the sector. Overall growth in operating revenues was expected to be above 3\%, which would outpace inflation and that, coupled with continued cost containment and efficiencies was expected to result in a more positive cash flow for colleges and universities in 2016. Over the following 12-18 month forecast period, all revenue streams were expected to grow, albeit at differing levels (see Figure 5 and 6). On an aggregate nation-wide basis, state funding was expected to increase in the $2 \%-4 \%$ range with expected significant disparities on a state-by-state basis. Revenue from endowments and gifts were expected to increase 4-5\%. 
In order to achieve cost savings, there was an expectation of enhanced collaboration among institutions over the outlook period as they sought to achieve efficiencies not only through purchasing consortia but also programmatically, via shared courses and even faculty. Moody's anticipated actual and virtual mergers of both public and private institutions and continued investment in facilities, such as core academic and classroom buildings, through a combination of debt, gifts, reserves and cash flow. Moody's asserted that continued reinvestment in facilities is an essential factor for maintaining a university's competitive position, both in attracting students as well as faculty. They expected debt issuance to continue to increase for public universities, as state capital support continues to decline. Moody's also noted that universities were increasingly examining public-private partnerships as a method to balance capital investment, competitive position and operating costs. (Behr, Fitzgerald, Tuby \& Smith, 2015)

In February 2016, Moody's weighed in on the global higher education sector. They stated:

Universities globally are confronting a period of significant transition. Higher education will be increasingly important to the world economy given the need for a well-educated and well-trained workforce. Growing demand and changing educational delivery models will be combined with a focus on efficiency and accountability... A university's ability to adjust to changing conditions will drive its credit strength and strategic position. (Fitzgerald \& Smith, 2016)

American universities had begun to expand their reach to meet the growing global demand for higher education. For public universities facing decreased government funding, allowing for diversification of the student base to include international students who will bear the 
full cost of their education is a sound strategy. However, in order to remain competitive, this global participation will require an investment in new, more flexible delivery models, which will put pressure on costs in the short run. The economic benefits of higher education are reflected across OECD countries. Income disparities have been noted, with adults holding a tertiary degree earning $60 \%$ more than those with just an upper post- secondary education. Additional income benefits accrue with education beyond the bachelor's degree, which would continue to drive growth in demand for master's degrees and higher. (Fitzgerald \& Smith, 2016)

In July 2016, Moody's issued a report that looked at state funding levels for the FY 2017. Public universities faced funding uncertainty and limited growth of tuition as well as funding tied to performance metrics in 32 states. Funding was impacted by low energy prices in states dependent on their energy economy such as Oklahoma, Louisiana and Kentucky. Other states, such as Illinois and New Jersey were facing funding constraints due to large pension liabilities. (Collins \& Smith, 2016)

Just prior to issuing their 2017 outlook, Moody's released the results of their annual tuition survey. Moody's reported net tuition revenue growth at a median 2.5\% for FY 2017 for private universities, and just $2 \%$ for public universities, down from $8 \%$ just five years ago. For both public and private universities, the gap is widening between larger, comprehensive universities and moderate- and smaller-sized institutions. Larger institutions have tuition revenue growth closer to $3 \%$. Smaller, private colleges are projecting declines in net tuition revenue for FY 2017. Projections for FY 2017 indicate that freshmen discount rates are up slightly from last year. Approximately half of small and moderate-sized private universities now have discount rates above 50\%. (Ortiz \& Smith, 2016) 
In December 2016, Moody's published their 2017 US Higher Education Outlook, and albeit with the warning that there were "clouds forming on the horizon", their outlook was stable. Their concerns focused on continued modest revenue growth, modest increases in state funding, and weak investment market performances. Although they projected that revenue growth will remain above 3\%, which will match expense growth, they also pointed out that increased competition and continued focus on affordability would put pressure on net tuition growth. (Ortiz, Fitzgerald, Behr, Tuby \& Smith \& Smith, 2016)

Enrollments are projected to grow modestly at $1.5 \%$ for 2017 and 2018, and increased retention rates will bolster revenue as more students stay enrolled. Moody's anticipates colleges and universities will be able to raise tuition as income and wages continue to rise and unemployment stays low. Moody's points out that the "enduring value proposition" of a bachelor's degree supports continued demand and "pricing power" through FY 2018. A bachelor's degree yields mean annual earnings of $\$ 75,000$ while a high school degree earns a mean annual salary of $\$ 35,615$, according to the United States Census Bureau Current Population Survey.

Government funding tied to performance metrics at public universities is expected to increase. These metrics include graduation rates and degrees awarded in specific fields and will be used to determine funding levels between state institutions. Private universities, which depend on $8-12 \%$ of their revenue from endowment income, are expected to see flat income due to weak investment performance in prior years.

In 2018, Moody's projects weakening revenue growth and rising labor costs, due to the prospect of rising inflation as the economy strengthens. This is typically accompanied by an increase in wages which constitute $60 \%$ of a university's budget. This will put pressure on 
operating cash flow margins. In addition to the concern over inflation, public universities, in particular, are facing exponential increases in pension costs if investment returns continue to lag. Other uncertainties include potential federal policy and funding changes that will impact student financial aid and research grants and contracts from the National Science Foundation (NSF) and the National Institutes of Health (NIH). This will result in the need to partner with other funding sources such as corporations and foundations, which tend to cover less of the administrative research costs.

Lastly, changes in immigration policies could profoundly affect international student enrollment in the US, and participation in the global higher education market in general. A decline in international student enrollment would place additional pressure on net tuition revenue. In addition, any policy changes under the Trump administration that discourage companies from hiring H-1B workers would discourage international student enrollment as well. A closer look at the rating methodologies that were used to examine, analyze and rate the entire U.S. higher education sector collectively, as well as individually for numerous public and private colleges and universities, will provide insights into the criteria Moody's uses to determine the financial strength and viability of U.S. higher education institutions. 


\section{Moody's Rating Methodology}

What does Moody's look at to determine their Not-For-Profit Higher Education sector outlook? Moody's relies on a rating methodology most recently revised in November 2015 (Kedem \& Yake, 2015). This methodology is used to assess credit risk for approximately 230 U.S. four-year public universities and university systems and 275 not-for-profit private colleges and universities, and collectively, for the overall sector. These rated colleges and universities enroll approximately $80 \%$ of all students at four-year public and private not-for-profit colleges and universities. This is equivalent to a financial checkup, and determines the financial health of individual colleges and universities and, in turn, the sector. It is a holistic, yet detailed, approach that examines and measures quantitative as well as qualitative factors and assigns a credit rating for the institution (see Table 1). Interestingly, the Moody's analysts cite the qualitative factors as just as significant as the quantitative during and after the Great Recession.

The most recent rating methodology incorporated changes to the August 2011 methodology previously used for ratings for the fiscal years 2014 and prior. The current methodology uses a scorecard as a basis for the rating discussion. The scorecard measures four comprehensive factors made up of ten sub-factors, a revision to the five broad factors used in the 2011 methodology it replaces. The scorecard does not solely determine the final rating; other factors considered include expectations of future performance, greater emphasis on one of the four factors or their sub-factors, and other relevant market data.

Factor One of the 2015 rating methodology is Market Profile, with a weighting factor of $30 \%$, consisting of three sub-factors, Scope of Operations, Reputation and Pricing Power and Strategic Positioning. Scope of Operations, as exemplified by Operating Revenue, indicates the 
financial strength of the institution with a greater scope of operations implying higher brand recognition, broader geographic diversification and the ability to exercise economies of scale when needed. Reputation and Pricing Power, as represented by Annual Change in Operating Revenue, represents the strength of the institution's brand to generate additional tuition income. Revenue growth is one of the key metrics that indicate the long-term health of an organization and its ability to grow revenue at or above inflationary levels over multiple years. Strategic Positioning is the result of prioritizing strategic investments in personnel, facilities and programs that enhance and strengthen the reputation and market position of the institution. Strategic positioning depends on long-range planning and competitive analysis to determine the proper level and the specific areas of investment and then identifying the funding sources.

Factor Two is Operating Performance, with a weighting factor of $25 \%$, consisting of two sub-factors, Operating Results and Budgetary Flexibility, and Revenue Diversity. Strong Operating Results are reflected in the ability to consistently generate cash and control expenses to yield a sufficient net income to support strategic operating and capital expenditures. A key indicator of sufficient cash to support these expenditures is Operating Cash Flow Margin. Budgetary Flexibility, the ability to increase revenue and/or reduce expenses, is critical in order to make changes if the operating environment changes. This has been a critical factor since the Great Recession. Revenue Diversity has also been a critical factor in the post-Recession world of weak revenue growth as it protects against an inconsistent or limited revenue source. Less reliance on a single source is considered credit positive.

Factor Three is Wealth and Liquidity, with a weighting factor of 25\%, consisting of two sub-factors, Total Wealth and Liquidity. Total Wealth represents sufficient financial reserves to withstand periods of instability in the operating environment. Key metrics are Total Cash and 
Investments and Spendable Cash and Investments to Operating Expenses, which look at absolute wealth and the assets that generate investment income and the ease of accessibility of wealth over time. Liquidity represents cash and investments that are unrestricted and are readily available for use. A key metric is Monthly Days Cash on Hand which measures the number of days' cash on hand, or that can be liquidated and accessed within 30 days, to support operating expenses.

Factor Four is Leverage, with a weighting factor of $20 \%$, and two sub-factors, Financial Leverage and Debt Affordability. Financial Leverage looks at financial reserves relative to debt and the key metric is Spendable Cash and Investments to Debt, which measures the ability of an institution to repay bondholders from sources that are accessible over time. Debt Affordability looks at the amount of resources that are consumed by debt payments, with the key metric being Total Debt to Cash Flow, which measures the ability to repay its debt from operating income, as opposed to reserves.

As mentioned previously, other credit considerations impact Moody’s assigned ratings. They look closely at credit trends over multiple years to determine the accuracy of universityprovided assumptions. They look at governance and management and their ability to develop long-range plans, measure performance and implement change as planned or needed. They also look at debt structure, government relationship and pension and retirement benefit costs.

The scorecard provides guidance for the elements that are generally most important in assigning ratings. Each sub-factor is assigned a weight and a value and allows for more objective and consistent application across universities.

The 2011 rating methodology, which was used for the ratings and sector outlooks through 2015, looked at five broad factors: Market Position, Operating Performance, Balance 
Sheet and Capital Investment, Governance and Management and Legal Security and Debt Structure. Strong Market Position allowed a university to compete effectively for tuition revenue, private gifts, research grants and government support. (Kedem, 2011) Moody's considered market reputation, scope of operations, student demand and pricing power and philanthropic support in their rating assessments of Market Position. Positive indicators of market reputation included brand identity consistent with the university's mission, number of distinct or high quality academic programs, and appropriately, identification, assessment and prioritization of risks and the application of resources to control them. Moody's looked at the size and diversity of operations, including alignment between programs and mission, ability and willingness to make changes in response to changing market preferences, and investment in programs of distinction. These criteria supported the idea that "there is no status quo". Student demand was measured by the number, quality and composition of applicants, as well as the depth of demand, which influences pricing power. Other factors include growth in the applicant pool, geographic diversity of students, and statutory and political flexibility to increase tuition and fees. Further, they look at a university's "sticker price" and tuition discount rates for its major programs. Philanthropic support is considered essential for strengthening a university's market position and Moody's evaluates the track record of meeting campaign goals and growth of donor support from a broad and diverse pool. The Market Position factor was replaced by a more streamlined Market Profile factor in the 2015 rating model.

Operating Performance is the second overall factor that Moody's looked at in the 2011 rating methodology. This consisted of an analysis of cash flow, budgetary flexibility and revenue diversity. Operating cash flow was analyzed in relation to the university's debt structure and debt service obligations. The ability to make timely adjustments to its operations, including 
the ability to generate additional revenue when an unanticipated event occurs, was assessed as well. Revenue diversity was measured by the existence of multiple, independent sources of revenue and an analysis of that revenue, i.e., research revenue/grants and healthcare revenue. This factor was essentially unchanged in the 2015 rating methodology.

The third factor in the 2011 rating model was Balance Sheet and Capital Investment. Balance sheets are often the most distinguishing strength for the sector. Management of the balance sheet has become increasingly important given the complexity of investment strategies and debt structures. In light of these asset and liability risks, liquidity had become a critical component of Moody's credit analysis as well. (Kedem, 2011) Access to external liquidity should an unforeseen event arise and well managed treasury, investment and finance functions within the university were positive indicators of liquidity. Appropriate levels of capital investment needed to be determined and funding through debt needed to be evaluated. The capital investment would ideally be either revenue generating or help maintain the attractiveness and competitiveness of the facilities of the institution. This factor closely aligns with Factor 3 in the 2015 rating methodology.

The fourth factor in the 2011 model was Governance and Management. This rating methodology took into account the non-quantitative indicators of governance and management to a greater extent than quantitative ratios over the long-term. The ideal board of trustees would have a mix of tenured and new members, with a mix of institutional history as well as external best practices, and the skills to provide expertise in risk management and financial matters. A strong CFO was viewed favorably as was experience from the business and/or government sectors. Strong oversight and disclosure would include board approved policies on investments, debt and liquidity, a strong internal audit function, board oversight of the President, detailed 
disclosure of student outcomes, financial statements and research activities posted on the university website, and term limits for board members.

Short and long term budgeting and planning and stress testing, along with prudent endowment management and close monitoring of risk factors were signs of good governance. Self-assessment and benchmarking were measured by establishment of best practices and key performance indicators, regular performance reviews of senior leadership, and in-depth institutional research and competitive analysis. Political autonomy from the state was credit positive but governmental financial support would strengthen the credit quality of a university. Good government relations are enhanced by strong local community relationships and substantial local and regional economic contribution from the university. This qualitative factor is assessed as part of Other Credit Considerations in the 2015 rating methodology.

The final factor is Legal Security and Debt Structure. These can have a direct impact on liquidity, cash flow, financial reserves and philanthropy. Positive factors would include bondholder security provisions, strong external financing terms, including diversity of counterparties, sufficient headroom under bank covenants, and access to a variety of debt products. This qualitative factor is assessed as part of Other Credit Considerations in the 2015 rating methodology.

In applying the 2011 rating model, the first three quantitative factors are assigned values and a weighted score and rating results. The last two non-quantitative factors are assigned a positive, neutral or negative rating and adjust the weighted score and rating accordingly. All factors are discussed in detail in the published rating reports. 


\section{Affordability}

The pressure facing American higher education during the Great Recession stemmed from an affordability crisis that hit the majority of families and individuals who either lost their jobs or had their savings seriously impaired (or both) as a result of the economic downturn and couldn't afford the cost of a college education.

Affordability had been a struggle for some time, as the cost of a college education had been rising twice as fast as the rate of inflation since the 1980s. Between the 1987-88 academic year and the 2007-8 academic year, tuition and fees rose on average 7.4 percent per year at public four-year schools and by 6.3 percent per year at four-year private schools. The inflation rate (measured by the Consumer Price Index) over this period averaged only 3.1 percent per year. (Archibald \& Feldman, 2011)

Critics were focused on the lack of spending control as the culprit in the affordability crisis; however, when the Great Recession caused declines in state funding of public institutions that became a focus as well. The solution to the problem of rising college tuition initially focused on expense containment and expense management, if colleges spent less, they could charge less. However, achieving that goal posed its own challenges. In their 1966 book, William Baumol and William Bowen, both economists, coined the phrase "cost disease", to describe the difficulty of increasing the productivity of workers in service industries, resulting in prices being driven up inevitably over time, including in higher education. (Archibald \& Feldman, 2011) With labor representing the vast majority of colleges' costs, the problem persisted and was driving up the cost to the consumer of a college education. Further studies supported these findings. Bowen continued to examine the problem, and in his 1976 President's Report at Princeton he concluded 
that the problem remained; as the price of a college education over the previous 10 years had risen 70 percent, prices in general rose only about 50 percent. (Bowen, 1976)

Archibald and Feldman (2011) noted that:

In the twenty-three years from 1947 to 1970, the real price of higher education grew 33.0 percent. In the next ten years it only grew 1.1 percent, just over a tenth of a percent per year. In the twenty-six years from 1980-2006, the real price of higher education grew 102.9 percent. (p. 29)

More recently, in 2013, a frequently cited study by Sandy Baum, Charles Kurose and Michael S. McPherson confirmed this trend as well, as they cited data from the Delta Cost Project that confirmed that "educational expenditures per FTE student increased at an average annual rate of about 1 percent beyond inflation at all types of public institutions from 2002 to 2008.” (p. 17-39)

Consultants and strategists outside the academic world turned their attention to the affordability issue and began to weigh in with recommendations. Bain \& Company, a global management consulting firm, brought significant attention to the challenges facing higher education when they issued a report authored by Jeff Denneen and Tom Dretler entitled, The Financially Sustainable University, in July 2012, declaring that "talk of a higher education 'bubble' has reached a fever pitch in the last year'. (p.1) The report cited four things (best practices) that innovative college and university presidents were doing to reverse this trend: Developing a clear core-focused strategy, reducing administrative costs, freeing up capital in non-core assets, and investing in innovative models. The healthiest organizations "stay true to their core business". The core is where they are most differentiated and where they derive their identity, which then guides the most effective channeling of resources. The authors 
recommended creating university-wide efficiencies of scale, citing data center management and the procurement function as good examples of functions that can be centralized or outsourced for greater efficiency and cost savings.

The report cited inefficiencies in organizational structure in colleges and universities, with most campuses having too many middle managers as defined by spans of control (numbers reporting directly to a manager). They also recommended better accountability in the area of expense management, whereby those who are responsible for achieving budget goals are also in a position to control the spending in order to reach those goals.

Another best practice recommended for private institutions, freeing up capital in noncore assets, could be accomplished by turning one of the largest assets on a college's or university's balance sheet, real estate, into cash which could be used to change the strategic trajectory of the institution. Yeshiva University followed this strategy when faced with a financial crisis; they sold real estate to create liquidity. Other assets that can be used to create liquidity, through sale and leaseback, include IT infrastructure and power generation facilities of an institution.

The Bain report also cited that institutional leadership must deliver the message that there is no status quo, change needs to be institution-wide, and that budgetary cuts will be based on priorities that are consistent with the institution's mission and differentiated strategy. The keys to a successful outcome are the clarity of roles and responsibility and functional and individual accountability. (Deneen \& Dretler, 2012) The Bain report echoed the need for financial prudence and a concerted cost-cutting effort to rein in costs in order to address the concern over rising tuition rates and the problem of affordability. 
Affordability has been a persistent problem and the issues go beyond cost-cutting. The affordability problem has its roots in the 1960s, propelled by the War on Poverty and Great Society initiatives that promoted "college for all." In order to open the doors to low-income families, and to try to meet the growing demand for highly-skilled college educated workers, the federal government took a need-based approach and provided Pell grants and subsidized loans to low-income students. (Bowen \& McPherson, 2016)

Even with efforts to bring down costs, decreases in state funding to public colleges and universities after the Great Recession were forcing tuition increases that were being passed onto the student. The average state funding decline (dating from the 1970s through 2010), caused by the need to fund rising healthcare and pension costs, has been almost 40\%. (Archibald \& Feldman, 2011) Hence, in 1970, states funded more than $50 \%$ of the cost of a public college, with tuition covering about $15 \%$; by 2012 , tuition represented more than $50 \%$ of the cost. With the ever-increasing tuition burden shifting to the student, student debt, often supplemented by private loans, has grown exponentially and created a growing "bubble" of its own. In fact, when compared to mortgage debt before the housing bubble burst, student loans grew by more than 6 times while housing-related debt increased only threefold from 1999-2008. (Sykes, 2016) Total student debt is $\$ 1.3$ trillion and rising, and has surpassed credit card debt in dollars and delinquency rate.

Student debt does however, represent an investment in education, and economic figures point to an increasing return on investment in a college degree. Data has shown that the return to a college degree tripled for women and nearly tripled for men between 1965 and 2009. (Bowen \& McPherson, 2016) Recent data also shows that by 2012, $71 \%$ of college graduates were 
financing that investment and incurred an average of nearly $\$ 30,000$ in student debt. (Carey, 2016)

Student loan defaults, as reported by the College Board, are about $9 \%$, with about $40 \%$ of the total being evenly split between public two-year colleges (19\%) and for-profit institutions (21\%). (Baum, Ma \& Pender, 2015) These default numbers are likely due to lower graduation rates at two-year publics and not-for-profits, as many students that don't graduate are not enjoying the college wage premium that comes with a bachelor's degree and allows them to repay their loans. When student debt does not result in college completion, the return on investment is compromised.

In summary, decreased state government funding has forced public colleges and universities to raise tuition and pass the burden of funding onto the student, who in turn, takes on increasing amounts of student debt to pay rising tuition. For low-income students who are saddled with student debt, the stakes are even higher to achieve college completion. This added pressure has highlighted another challenge: The need for greater educational attainment and securing of the college wage premium.

This challenge will be examined next through the lens of economic theory and how educational attainment impacts productivity, the standard of living and the economics of higher education. 
Economic Theory, Income Inequality and Higher Education

Economic theory suggests that factors impacting the cost of higher education are economy-wide factors, not specific to the sector. Economic productivity, defined as the ratio of outputs to the inputs used to produce them, is at the core of the discussion on economic theory and higher education. Technological progress, in turn, is central to discussing economic productivity which tends to lag in service-providing industries such as higher education. Technological progress has produced significant growth in labor productivity in goods-producing industries; specifically, manufacturing productivity tends to be greater than service industry productivity as a result of efficiencies that technology brings to the manufacturing process which yield lower costs. As technological progress expands in the goods industries, the demand for skilled workers increases, which drives up wages and creates a wage differential between highly skilled and low skilled workers.

Higher education is labor intensive and demands highly educated workers whose higher wages drive higher costs. William Baumol and William Bowen, in their 1966 book, analyzed this labor intensive scenario in the performing arts and argued that prices in the performing arts would have to rise more rapidly than prices in general as labor productivity in the performing arts is much more difficult to increase. As mentioned earlier in the previous chapter on Affordability, this came to be known as "cost disease", which occurs when lack of productivity causes rising costs in service industries and, in turn, rapidly rising service prices. (Baumol \& Bowen, 1966) They assigned this as the cause of the rising costs in higher education, and the subsequent rise in tuition prices over the next four decades. 
Archibald and Feldman (2011) offer data that shows that higher education prices behave similarly to prices of other services offered by highly educated workers and these prices have been rising rapidly since the 1980's. They also observed that escalating higher education prices diverged from the path of prices for less skill-intensive services around 1980. Other economic data, from a 2008 book by Goldin and Katz shows that wages for these highly educated workers increased rapidly around 1980 as well, resulting in the rapid rise and sustained growth in the rate of return on a year of college referred to as the college wage premium. (Figure 7)

This accelerated rate of return on college was fueled by skill-biased technological change and the laws of supply and demand. Skill-biased technological change occurred throughout the twentieth century and has steadily raised the demand for skilled workers. For most of the $20^{\text {th }}$ century, the educational system was able to meet demand for skilled workers by producing more graduates. In the late 1970's the number of college graduates began to slow while demand for their skills continued to grow. The resulting shortage of highly educated, skilled workers drove wages up and created a widening gap in income inequality between highly skilled and lowskilled workers. Archibald and Feldman (2011) call this the "hollowing of the middle class". (p.62)

The twentieth century came to be known as the "American Century" as a result of American political and economic dominance beginning after WWI. The U.S. experienced a rapid rate of economic growth, technological advancement and educational attainment, along with declining income inequality and a higher standard of living, until the 1970s. This period of economic growth was fueled by labor productivity that had been rising almost three per cent annually from 1947-1973, followed by less than half that productivity (1.4\%) from 1973-1995. (Goldin \& Katz, 2008) Although productivity resumed at an annual rate of three per cent from 
1995-2005, economic inequality persisted. The supply of highly-educated workers did not keep pace with demand and the result was an increasing college wage premium which increased and widened the gap in income distribution. (Figure 8)

Economic analysis shows that changes in the supply of educated labor had a much greater effect on wages than changes in demand for skilled labor. While the supply of college educated labor increased $3.9 \%$ from 1960-1980, it declined to $2.3 \%$ (a 50\% decline) from 1980-2005. (Goldin \& Katz, 2008) Educational attainment has not kept pace with the demand created by technological changes. This has resulted in an increasing wage gap between highly-skilled and low-skilled workers and is the root cause of the growing economic inequality that persists today. (Figure 9)

In summary, educational attainment grew very rapidly during the first three quarters of the $20^{\text {th }}$ century and kept pace with the demand for college-educated workers. As a result, economic inequality declined. Over the last quarter of the $20^{\text {th }}$ century, educational attainment slowed significantly and resulted in a shortage of college-educated workers which caused a wage differential that became known as the college wage premium. This caused a substantial widening of the U.S. wage distribution as measured by Goldin and Katz (2008), from 19632005.

Several recent studies have confirmed the growing gap in income between the lowest and highest income earners. A groundbreaking study published in December 2016 by Piketty, Saez and Zucman, "Distributional National Accounts: Methods and Estimates for the United States" used more comprehensive data to analyze the trends in greater detail than ever before. The study combined tax, survey, and national accounts data to build new series on the distribution of national income since 1913. The data includes information on fringe benefits, labor and capital 
income earned, taxes paid, transfers received, wealth owned, etc.- - by age groups, gender, and marital status. Their findings show:

The bottom $50 \%$ income share has collapsed from about $20 \%$ in 1980 to $12 \%$ in 2014 . In the meantime, the ...top $1 \%$ adults... income share increased from about $12 \%$ in the early 1980s to $20 \%$ in 2014 . The two groups have essentially switched their income shares, with 8 points of national income transferred from the bottom $50 \%$ to the top $1 \%$. The top $1 \%$ income share is now almost twice as large as the bottom $50 \%$ share, a group that is by definition 50 times more numerous. In 1980, top $1 \%$ adults earned on average 27 times more than bottom $50 \%$ adults before tax while today they earn 81 times more. (p. 4) They go on to recommend policy changes that would raise educational outcomes and skills attainment:

Even after taxes and transfers, there has been close to zero growth for working age adults in the bottom 50\% of the distribution since 1980. [ ] Policies that could raise bottom 50\% pre-tax incomes include improved education and access to skills, which may require major changes in the system of education finance and admission; reforms of labor market institutions, including minimum wage, corporate governance, and worker codetermination; and steeply progressive taxation, which can affect pay determination and pre-tax distribution, particularly at the top end (see, e.g., Piketty, Saez and Stantcheva 2014, and Piketty 2014). (p. 4)

Another study released shortly thereafter, in January 2017, by Raj Chetty of Stanford University and others, "Mobility Report Cards: The Role of Colleges in Intergenerational Mobility", examined the effect that educational attainment has had on socio-economic status. 
The Chetty et al study measured each college's upward mobility rate as the fraction of its students who come from the bottom quintile of the income distribution and end up in the top quintile. It captured rates of intergenerational income mobility at each college in the United States using administrative data for over 30 million college students from 1999-2013. (Chetty, Friedman, Saez, \& Yagan, 2017) The findings showed that the earliest results identified many colleges that were providing upward mobility for students in the bottom fifth of the income distribution to the top three-fifths of the distribution, among them City College of the City University of New York, Baruch College and Stony Brook University, all public institutions.

The data also showed that the fraction of students from low-income families at schools that showed the highest mobility rates fell sharply into the 2000's, likely becoming less accessible to them because of affordability/funding issues. If, in fact, there is some value added at the schools with high mobility rates, according to the authors, "they could provide a scalable model for increasing upward mobility for large numbers of students, as they have median annual instructional expenditures of $\$ 6,500$ per student, far lower than median instructional expenditure of $\$ 8,700$ per student at elite private colleges." (Chetty, Friedman, Saez, \& Yagan, 2017, p. 40)

The wealth gap between young and old is also widening. U. S. households headed by a person 65 and older has a net worth 47 times greater than household headed by someone under 35, which is more than double what it was is 2005. (Craig, 2015) Economists also point to wage stagnation in the middle class (while incomes rise for the top 1 percent) as contributing to the widening wealth gap. (Bowen \& McPherson, 2016)

With educational attainment so central and critical to economic growth, it is useful to look at ways that productivity can be enhanced in higher education to offer some relief in the rising cost of a college education and increase the rate of college completion. Technology has 
not yielded measurable productivity gains in higher education as it continues with the same or greater use of highly skilled workers with no gain in output. As a result, costs and prices are rising even with the adoption of technology. A closer look at productivity gains shows that technology has produced quality improvements which are difficult to measure, a problem in service industries in general. Improvement in quality has been called "hidden productivity," (Archibald \& Feldman, 2011, p.71) such as the ways that technology is making it possible to better measure the acquisition of knowledge. Other quality enhancements due to technological change that result in hidden productivity include course management software like Blackboard, statistical software to enhance research, smaller group seminars, student services, such as heath, career, counseling, advising and enhanced facilities. These all raise costs but also raise the quality of the service.

Higher education, as an industry, is at the core of the economic engine of our country. The outputs of higher education are the inputs of other industries and if students aren't prepared for employment using the latest technology and skills, they will not be able to contribute to meet the demands of highly-skilled jobs that fuel our economy. In a sense, colleges and universities must meet a "standard of care" expected of them by students and those who fund higher education, including donors and governments. (Archibald \& Feldman, 2011, p.76)

In the area of research, higher education is committed to "expanding the frontier of knowledge"( Archibald \& Feldman, 2011, p.78), which requires giving faculty and students the tools they need, which are cutting edge, expensive and can initially decrease productivity; but research itself can lead to productivity growth. The commitment to the creation of knowledge that yields productivity growth can, in turn, create higher standards of living. There is also the 
possibility that as the type of knowledge changes, it will require less expenditure of resources and will result in true productivity growth.

Economic growth, in the form of productivity gains, raises the standard of living by raising wages and is responsible for rising costs in the higher education industry. Without productivity gains, the decision makers in higher education can only hold down costs at the expense of quality or enhance quality with an increase in costs. The quest for increased productivity in higher education lies with the implementation of a lower cost educational delivery model that is less labor intensive.

Instructional technology and innovation, which will drive productivity growth in the economy and within higher education, will be explored next. 


\section{Instructional Technology and Innovation}

Technology in higher education came under sharper scrutiny during the Great Recession. Technological change possesses a multi-dimensional character yet, like the affordability crisis, points to the potential for disruption that has been building over time. In the 1990's, the Internet had a major effect on how university research was conducted, distributed and archived, but did not have a disruptive effect on higher education in general, as the industry settled into a decade of tuition hikes, administrative bloat and continuation of the hybrid model, defined by Carey (2016) as a blend of practical training, research and liberal arts education.

William Bowen, former President of Princeton and founding chairman of ITHAKA, had been among those from traditional higher education who gave a greater voice to the need to embrace technology in ever increasing ways. Bowen (2015) noted that technological innovation had led to dramatic improvements in the scholarly infrastructure. He cites in his Tanner lecture of 2012 how, "the creation of JSTOR (a highly searchable electronic database of scholarly literature) has changed fundamentally the way scholars use the back files of journals and has had profound effects on libraries." (p. 8) The potential for other profound impacts from technology began to dominate the higher education conversation. Technological innovations accelerated progress in the science of learning and pedagogical advancements, which offered completely new ways to deliver and measure learning. Anthony Picciano (2017), Professor and Executive Officer of the PhD Program in Urban Education at the City University of New York, in his latest book, Online Education Policy and Practice: The Past, Present, and Future of the Digital University, describes this as the Fourth Wave (2014-2020) of online education, which began in the 1990's. He sees this current wave "as one where pedagogy is driving technology in a 
comprehensive and sophisticated blended learning environment relying on a variety of digital resources developed by individual faculty, by well-financed MOOC companies, and by corporate education service providers.” (p.20) Blended learning, described by Picciano (2017) as emerging as part of the Second Wave, brought Internet technology into the classroom to enhance, and sometimes replace, traditional face-to-face courses in the early 2000's.

Technological developments in the science of learning, particularly since the early 2000's, are creating sweeping possibilities for enhanced learning and learning outcomes. These developments also hold the possibility for significant productivity gains that could dramatically change not only the economics of higher education, but the attainment rates that are essential to fuel the US economic engine.

With so much at stake, there is much attention on and interest in the area of pedagogy. Studies have shown positive learning outcomes for online delivery models that are being combined with traditional classroom models. There are discoveries in cognitive learning that are creating individualized as well as competency-based learning models. The impact of these enhancements can have a substantial effect on time-to-degree, graduation rates, learning outcomes and job preparedness. The winds of change in higher education are swirling around pedagogical transformation.

The technological innovations that are poised to significantly impact higher education focus on various pedagogical changes to the delivery model. Online Competency-Based Learning, Immersion Programs, Adaptive Learning and Gamification are all in various stages of development and are being studied, reviewed and their outcomes measured.

Online competency-based learning is a method designed to teach, develop and assess cognitive capabilities such as problem solving and numerical reasoning as well as behavioral 
characteristics such as teamwork. Competency-based learning (CBL) has the potential to be extremely cost effective versus standard online delivery as well. (Craig, 2015) Cost savings are derived from this model in several ways. First, this model can effectively utilize less expensive adjunct faculty versus tenured faculty to facilitate and monitor learning. In addition, there is less "seat time", which results in shorter time to completion and a reduction in related expenses (i.e., facilities and other administrative salaries and expenses). Lastly, as use of the CBL model increases, economies of scale result that would reduce the per student cost to administer.

One of the challenges of online learning is maintaining student focus; this is accomplished by creating a flow that draws the student in by making the work challenging, but not impossible, setting clear goals and giving consistent feedback. Conventional platforms that use "controlled focus" would include language immersion programs and the overall traditional campus experience, which engages students in all aspects of campus life. (Craig, 2015)

Adaptive learning contrasts the "single stream of instruction" of the conventional instructor-led classroom by letting students learn at their own pace. It is being combined with competency-based learning in a costly model that is being funded by private companies like Apollo, American Public and Career Education that own for-profit institutions and have the capital to develop the technology or acquire companies that have already done so. (Craig, 2015)

Gamification is an online learning method that incorporates elements of reward and recognition, keeping students motivated to keep moving through the material. How effectively these delivery models are incorporated into traditional higher education remains to be seen.

George Otte, University Director of Academic Technology at the City University of New York, points out that "patterns of adopting (or resisting) technological innovations are well established" throughout history. Otte goes on to say: 
Technology has made possible what our world has arguably always needed and now needs more than ever: modes of instruction that break with a broadcasting model of teaching to a networked communication model....Faculty are not irrelevant to this model. On the contrary, they are arguably more important than ever before, structuring the [student] learning experience...identifying the key issues and tensions, suggesting the right elements to synthesize (and, ideally, learning from and sharing with one another as they do all this). (Goldstein \& Otte, 2016, pp. 68-69)

No doubt, faculty is critical to driving institutional change around pedagogy. Cathy Davidson, Director of the Futures Initiative at the City University of New York, has been a key driver of pedagogical change in the area of connected learning and credits the Internet as the stimulus for peer learning, which enables students to gather for themselves, test and apply knowledge in teams and ultimately to build new knowledge. In 2002, Davidson cofounded an innovative learning network, HASTAC (Humanities, Arts, Science, and Technology Alliance and Collaboratory) as a repository for sharing ideas and research. In 2015, Davidson co-taught the first Futures Initiative course, Mapping the Futures of Higher Education, "to train the next generation of college professors... as innovators of pedagogical and institutional change." (Goldstein \& Otte, 2016)

Just as their predecessors, distance learning and asynchronous learning, new approaches to teaching and learning are student centered, not teacher centered. Students are constantly assessed to be sure they understand the material and remediation is available through tutors and mentors as "the goal is to ensure mastery by every student." (Goldstein \& Otte, 2016, p. 120) This mastery is imperative to success in our $21^{\text {st }}$ century economy. Employers are seeking specific competencies which these new modes of learning can measure. Students will be 
entering an increasingly ambiguous world where "what you know and remember" is far less important than "how you can apply, analyze, evaluate and create." (Goldstein \& Otte, 2016, p. 131)

The traditional "sage on a stage" model of teaching was, and continues to be, challenged, as the capability to customize learning and measure learning outcomes experiences rapid development. That these advances in learning can be delivered online to a larger population at a more affordable cost (due to economies of scale), is extremely compelling. That they represent the first significant improvement in productivity in higher education make them even more compelling. These advances appear to have a significant positive impact on graduation rates as well. So what's the problem?

Traditional higher education is slow to change and predictably, has raised many questions and concerns about the efficacy of rapid change and its effects. One of the pressing concerns is a reduced and changing need for labor (human capital), and herein lays the problem which is challenging workplaces everywhere. Specifically in higher education, alternative online teaching platforms require less face-to-face teaching time, significantly changing the role and the need for faculty. Currently, faculty view their mode of educational production as artisanal; and as artisans, will fight to protect their autonomy, even at the expense of productivity. Because of the shared governance model in higher education, faculty have a strong voice and very strong reactions to the significant economic and social implications of automating learning and thus, teaching; but the idea of a lower cost, more efficient and effective delivery model is compelling.

Nonetheless, the technology revolution, to this point, has had almost no effect on price or how students learn, as professors have not embraced change for fear of losing their jobs and because of the existence of "normative isomorphism", becoming used to doing things in certain 
ways. This concept is adapted from the work of Yale sociologists, Paul DiMaggio and Walter Powell, who developed the concept of "institutional isomorphism," whereby organizations within a given field have a tendency to become more and more like one another over time. (Carey, 2106) Cautiously embracing technological change remained the norm.

Online education, in the 1990's, became synonymous with for-profit higher education as enrollments soared and its presence was felt. The most widely-known for-profit institution, University of Phoenix, established in 1976, and acquired by the Apollo Group, a higher education investment group, in 1981, experienced rapid expansion and growth while using the ALN model of online education. Just as University of Phoenix enrollment peaked at 471,000 students in 2010, The Education Trust, a non-profit advocacy group, issued a report that disclosed their disappointing six-year graduation rate of $9 \%$; this, coupled with its low-income students burdened with significant student debt, created a negative picture of the entire for-profit higher education sector. (Picciano, 2017) However, that is rapidly changing, as the for-profit education industry consolidates and improves its product, its image and its ability to improve student persistence and outcomes through the collection and analysis of data to enhance adaptive learning, a much-improved delivery model over the previously-used ALN. (Craig, 2015)

Flexibility is another driving force in the technology discussion. The need for flexibility has been building over time as the demographics of the student population are changing, in ways that support the use of online delivery models. The growth in the non-traditional student population, older and working, or from a lower income background and working, demand the flexibility and efficiencies that online learning offers. The opportunity for reduced time-todegree through competency-based online learning has the potential to yield higher numbers of and more timely degrees earned. Several institutions have adopted the CBL model, among them 
Western Governors University, which began operations in 1999, but has only a $6.5 \%$ graduation rate. (Picciano, 2017) Nonetheless, the online education concept drew increased attention and support when ITHAKA, under the direction of William Bowen, conducted a large-scale randomized control study in 2011, showing that learning outcomes were virtually the same or better for courses taught through a blended mode (partly online, partly in class) versus through the traditional course mode and in half the time. (Goldstein \& Otte, 2016). Further studies were inconclusive, but the message was clear; instructional technology was making its case.

The loyalists have proceeded very cautiously in implementing technological changes to higher education institutions. As discussed, various stakeholders are weighing in on this topic: thought leaders that include educators, administrators, policymakers, journalists and venture capitalists, with complementary and competing points of view and visions.

At the same time that technological innovation was advancing and online learning was evolving in the 1990's, Clayton Christensen was popularizing a theory of innovative disruption of free markets. During the Great Recession, Christensen applied his theories of disruption to technology as a disruptive force in higher education. (Christensen \& Eyring, 2011) His theories were criticized by higher education traditionalists and dismissed by many. Some institutions, however, embraced technology and incorporated online learning into traditional higher education to create what would be the first blended models (traditional classroom and online). Most notable of this group are Arizona State University (adaptive learning), University of Central Florida (adaptive learning) and Southern New Hampshire University (CBL). (Selingo, 2013) These programs remained the pioneers for blended learning, without too many other institutions following suit. At the same time, MOOCs (Massive Online Courses) were experiencing their own growing pains. Between 2008 and 2013, many MOOC companies were created and 
enrollments grew to "massive" numbers; but a major setback came in 2013 after San Jose State University in California offered a number of mathematics and statistics courses using MOOC materials and the results were not very positive. (Picciano, 2017) With 90\% dropout rates and no credentialing upon course completion, MOOCs never really emerged in the way that was originally expected. (Craig, 2015)

Nonetheless, continued interest in the concept of reaching a massive audience has drawn the attention of venture capitalists and other investors to the education sector. Along with healthcare, the education sector is the fastest growing industry sector in our economy today. This investment has created a start-up culture that is having a growing impact on the education sector and has attracted talent from traditional higher education, including college presidents and distinguished faculty members who want to be part of the change. (Carey, 2016) Kevin Carey, who directs the Education Policy Program at the New America Foundation, has deemed this the start of the University of Everywhere, a personalized, individualized tutorial education to large numbers of people at a reasonable price. (Carey, 2016)

The Information Age requires newly minted skills, and students, who have been failing to graduate or graduating with debilitating student debt, demand the credentialing that employers are looking for. These demands are large contributors to the impetus for pedagogical change that will ensure that higher education continues to yield a return on investment for degree-seeking students and lifelong learners. A closer look at achieving job readiness follows. 


\section{Job Readiness}

The concern over job readiness is one of the most critical challenges facing higher education in the $21^{\text {st }}$ Century. Research has shown that education is not a predictor of job readiness; the 1984 meta-analysis by John Hunter and Ronda Hunter demonstrated that formal education was a relatively poor predictor of job performance. (Hunter \& Hunter, 1984) They found that a combination of three scores on different cognitive skills tests (calling it "ability composite") was five times more predictive of job performance than being a degree holder.

This was confirmed by feedback from employers in a more recent study, Jobs for New York's Future: Report of The City University of New York Jobs Taskforce 2012, where employers cited the skills in demand, as follows (Spaulding, Hirsch, Kauder, Desmond \& Duitch, 2012, p.6):

- An appropriate balance between deep, specific skills and general knowledge, referred to as "T-shaped skills" i.e., immersion in one field and broad knowledge across other fields

- Creativity and curiosity and a broad understanding of the world that is often obtained from a well-rounded liberal education

- Written and oral communication skills; that is, the ability to effectively articulate and present ideas

- Analytical skills, namely the ability to arrange, understand, assess, and interpret increasing amounts of data 
This employer feedback confirms that cognitive ability is highly valued and that mastery of any specific knowledge should be balanced with broad knowledge across disciplines; what is equally valued is "one's ability to interpret, sort, organize and make sense of information on the job"....whether the task is "developing a product, addressing a customer complaint, or designing a new strategy". (Craig, 2015, pp.120-121)

Behavioral skills are also important to employers. According to Peter Cappelli, director of the University of Pennsylvania Wharton School's Center for Human Resources:

[The employers'] list is topped not by a cluster of missing technical or academic abilities but by a lack of work attitude and self-management skills such as punctuality, time management, motivation and a strong work ethic. Indeed, the absence of these traits, which used to be called "character traits", repeatedly shows up as a primary concern in numerous studies. (Cappelli, 2012)

Using assessment data, institutions could ascertain which programs produce better results with regard to cognitive and behavioral skills, then define best practices and incorporate them into the curriculum. This could prove highly differentiating for universities and highly beneficial for students.

Schroder and Cook (2016) point out that "the disconnect between education and the needs of society became obvious by the turn of the $21^{\text {st }}$ century." They go on to say: Michelle Wiese, senior research fellow in higher education at the Clayton Christensen Institute for Disruptive Innovation, put it well: "Something is clearly wrong when only $11 \%$ of business leaders-compared to $96 \%$ of chief academic officers-believe that graduates have the requisite skills for the workforce (2014). (Goldstein \& Otte, 2016, p.118) 
Higher education is feeling pressure from both students and employers to ensure that students graduate with the relevant skills that the job market requires. Students and employers are making that demand heard, which has prompted colleges and universities to track and publish employment outcomes for their graduates for use in making college selection decisions. Students are looking to ensure a return on investment, particularly since the rising cost of a college degree has made the investment more substantial. With the majority of students incurring significant amounts of student debt as well, the return on investment must equate to securing a job that will allow for debt repayment as well as a living wage. To further complicate this situation, U.S. 6 year college graduation rates are about 55\%. (Craig, 2015) Higher education has addressed the pressure to meet employers' expectations for job preparedness in several ways. They are in the process of adopting online competency-based learning which offers lower cost and measures mastery of various cognitive skills which align with job-related skills. Curriculum reform and course redesign recommendations have come from faculty leaders such as Robert Zemsky and William Massy, but change has been slow to occur in traditional higher education.

Much of the response to demand for job-preparedness has come from the for-profit education sector, whose institutions have been called "industrialized universities" by William Massy. (Zemsky, 2013, p. 168) Their courses are designed top-down and delivered using online and hybrid models in a standardized way that is easily replicated at a low cost. The forprofits have reached out to non-traditional adult learners who are looking for a lower cost, flexible (online) option that is more job-centered, more aligned with training, and have higher completion rates, than a traditional college or university. This option offers short-term goals such as certificates or licensing that allows for successful entry into the job market. 
The for-profit sector is funded by investors from Silicon Valley that have the resources to invest in start-ups that are developing innovative educational alternatives. Their goal is to provide a low-cost education to anyone, anywhere. They have identified the education industry to be a $\$ 4.6$ trillion industry globally, with the marketplace being the global middle class which is growing from 1.8 billion in 2009 to 3.3 billion in 2020 to 4.8 billion in 2030. (Carey, 2016)

Traditional higher education has invested in experiential learning in the form of internships, co-op programs and workforce training programs at the community college level. Some private colleges are looking to increase employer alliances to align graduates and the job market more closely.

American higher education has responded to the demand for skilled workers throughout its history. It has been and continues to fall short of meeting this demand; how it will address this critical challenge will be discussed in conclusion. 


\section{Conclusion}

Higher education has always been slow to change. Frederick Rudolph, in his comprehensive 1960 study of the history of higher education in America, acknowledges this fact:

Resistance to fundamental reform was ingrained in the American collegiate and university tradition, as over three hundred years of history demonstrated.... Except on rare occasions, the historic policy of the American college and university [is]: drift, reluctant accommodation, [and] belated recognition that while no one was looking, change had in fact taken place. (p. 491)

Rudolph, could, in fact, be describing the process taking place right now in higher education. Starting with technological innovation, which is all around us and has transformed virtually every industry, we see what Rudolph calls "belated recognition" and "reluctant accommodation" in the higher education sector. More than any other factor, technological innovation has the potential to have the greatest, far-reaching impact on the issues facing higher education and the demand for its product. Integrating technological advances into the area of pedagogy alone will have a positive impact on affordability, educational attainment, productivity, job readiness, and globalization.

From Clark Kerr (2001), an economist by training, who urged, in his last essay in Uses of the University in 2001, to use "information technology more widely and more effectively", to digital education and innovation leaders like James Devaney and James Hilton at the University of Michigan, who believe that "if institutions focus on [their core mission], if they search for meaningful differentiation and if they embrace the opportunities that digital technology bringsthen the future is bright." (Goldstein \& Otte, 2016, p. 157), the message is clear. 
In their 2014 higher education sector outlook, Moody's looked at online learning as "credit positive" and pointed to competency-based learning and unbundling of services to increase mobility across institutions, as well as increasing access and flexibility to students, as strengthening and stabilizing colleges and universities financially and operationally. They also noted that globalization represents the challenge of increased competition for students which online learning could address. Global competition for international students continued to be a concern in their 2016 and 2017 sector outlooks; with tuition growth already a significant concern, a decrease in international students, who typically pay full sticker price for tuition and help diversify and boost tuition revenue, would put additional pressure on tuition growth. Endorsement for technological change is coming from academic leadership as well, as Matthew Goldstein, former Chancellor of the City University of New York, notes: ...Greater use of digital platforms for teaching and learning holds great promise for significant cost containment and better understanding of the elements that lead to successful completion of degree requirements... There is little doubt that serious efforts will be made in reinventing the ways universities educate their students. And technology will play a leading role. (Goldstein \& Otte, 2016, p. 44)

There is a definite consensus among various higher education stakeholders that the profound impact of technological innovation on higher education is already being felt. Policymaker with the New America Foundation, Kevin Carey, speaks of the anticipated unbundling of the traditional hybrid university, as Silicon Valley start-ups are developing various software that present a different value proposition to students. Some examples include learning software that produces knowledge credentials that can demonstrate skills and competencies to employers. Others, like the Minerva Project, a low-cost education start-up competing as an 
alternative to the elite universities, are gaining momentum. As Carey points put "information technology will allow for the creation of many new and different higher education institutions that offer a much better education at a much lower price.” (Carey, 2016, p. 142)

Ryan Craig, a venture capitalist in the higher education space, also sees the unbundling of traditional higher education as inevitable. Unbundling removes the things that don't relate to student outcomes such as housing, food service, athletics, career services, admissions and research, and focuses on what Craig (2015) calls "the content bundle", basically all coursework, remedial, general education or major-related. Unbundling significantly reduces the cost of education. The content bundle as a low-cost online offering can be customized for international markets, which is believed to be a $\$ 160$ billion opportunity. Craig sees bundling continuing however, where it continues to create "clear value or return on investment for students relative to unbundled alternatives." (Craig, 2015, p. 210)

William Bowen, president emeritus of Princeton University and founding chairman of ITHAKA, noted signs of unbundling taking place on traditional campuses. He observed "the early stage of at least a partial unbundling of activities that used to be the responsibility of a single faculty member or of groups of faculty in a single campus location.” (Bowen, 2015, p.66) Bowen also anticipates collaboration across institutions, such as a pooling of resources for purposes like offering common introductory undergraduate courses.

Alternative online delivery models will continue to address the most pressing issues challenging higher education- affordability, educational attainment, productivity, job readiness, and globalization. A lower-cost, unbundled product eases affordability, as competency-based learning, as an example, has the potential for shorter time-to-degree along with greater educational attainment. Productivity is increased by lowering inputs and getting the same or 
greater outputs. Job readiness is enhanced with knowledge credentials that are attractive to employers. And finally, globalization is achieved through the investment in the development and offering of online learning for global consumption.

Thought leaders in higher education are envisioning and endorsing a revamping of the traditional higher education delivery model. Robert Zemsky (2013) sees the possibility of a dual-track college system; one track consisting of research-focused institutions and elite private liberal arts colleges and the other more training-focused and comprised of all other institutions, including for-profits. Craig (2016) envisions a similar two-tier system along the lines of the "bundled elite and unbundled for everyone else." (p.210) He sees the emergence of a "digital divide "that will segment higher education providers into job-focused and employer-friendly institutions and traditional campus-based institutions" but that over time the two will start to look more alike as traditional institutions begin to adopt some of the online learning models. (p.212)

The road to change in higher education travels through the faculty, as they are at the core of the institution and its education delivery model. What is needed, both individually and collectively, is a willingness to "re-conceptualize their responsibilities"-curriculum redesign, scholarship and learning, collaborative teaching, in the interest of managing costs. (Zemsky, 2013, p. 171) A dual-track faculty system would offset the need for a two-tier college system by having faculty (both tenured and non-tenured) dedicated to either research or instruction in the same institution. This is a time when faculty leadership is greatly needed to deal with the realities of limited resources and how to best utilize those resources to maximize productivity and maintain a quality product.

The need for strong executive leadership to tackle the tough choices and challenges facing higher education is receiving unanimous backing from higher education stakeholders who 
are voicing their support. Clark Kerr (2001) asserted that "most successful new policies in higher education have come from the top." (p. 136). Bowen and McPherson (2016), in their book, Lesson Plan, asserted that there is an urgent need for senior leadership to "engage in real experimentation, which inevitably entails risk-taking [otherwise] higher education is unlikely to take full advantage of technological advances that offer real promise of improvement in educational outcomes while controlling costs." (pp. 70-71) They go on to say, "Presidents should be expected to promote risk-taking and experimentation and should not be afraid to 'rock the boat'. This is especially true in the area of teaching methods... with rigorous assessment of what works and what doesn't work at each step of the way.” (p. 136) Matthew Goldstein echoed these sentiments, as Clark Kerr did in 2001, when he saw the future filled with uncertainties and discontinuities; and Goldstein (2016) acknowledged that "Leadership must truly lead, not just track trends, and must be both venturesome and cautious.” (p. 50) Finally, Moody’s values leadership as well, and assesses leadership as part of their rating review. They look at governance and management and their ability to develop long-range plans, measure performance and implement change as planned or needed.

Government plays an enormous role in the higher education equation as it is responsible for a significant portion of its funding. It is also a growing area of uncertainty as the states are grappling with rising healthcare and pension costs and the federal government is trying to rein in spending. Higher education needs to look at alternate sources of funding including partnerships with the private sector and other colleges and universities and increased reliance on fundraising from alumni and others.

The purpose of this study was to research and review the current literature to determine how American higher education should address the challenges that are impacting the demand for 
its product: affordability, pedagogical innovations, student debt, government funding, graduation rates and job placement outcomes. More specifically, the goal was to take an in-depth look at what changes American higher education will make to deliver the value proposition that will attract and graduate the maximum number of students. A survey of the current literature on these issues has revealed multiple options and strategies to address the challenges as discussed throughout this study and in conclusion.

First and foremost, embracing technological change in the area of pedagogy yields the most wide-reaching benefits in addressing all the other challenges. One of the benefits includes maintaining its value proposition by offering higher quality learning at a lower cost (over time) that will attract and graduate the maximum number of students. The resulting increase in attainment rates will increase productivity by increasing the supply of highly skilled, collegeeducated workers and, thereby, the value proposition will be realized when these graduates earn a college wage premium on their investment in education. So too, will the continued emphasis on the creation of knowledge lead to productivity growth and a higher standard of living. In addition, continued efforts in the area of creating a scalable model for increasing upward mobility, as demonstrated by the results of the January 2017 Chetty et al study "The Role of Colleges in Intergenerational Mobility", will help shrink the widening income gap and reduce overall income inequality. As well, with the uncertainties of government policies in the areas of funding and immigration, it is even more important that higher education embrace change proactively in areas that it can control, like technology. Moody's identified these two areas, the possibility of federal funding and immigration policy changes as areas of concern also, in their 2017 sector outlook. 
To reiterate, the emergence and presence of strong leadership and responsible governance that is willing to embrace change is imperative. Clark Kerr (2001) saw discontinuities and uncertainties when he looked at the future of higher education in 2001. He spoke of the university as a "City of Intellect", as a university city with its satellite suburbs. He also viewed it in a wider context, as "encompassing all the intellectual resources of a society, and the even broader perspective of the force of intellect as the central force of society-its soul. Will it be the salvation of our society?" (p.92) The Golden Age of higher education, as described by Kerr, has passed; but its central place and the demand for its product in our society still endures. 
Table 1: Moody's Credit Ratings and Definitions (from Rating Methodology, August 2011)

\begin{tabular}{|c|c|c|}
\hline \multicolumn{3}{|c|}{ Moody's credit ratings } \\
\hline \multicolumn{3}{|c|}{ Investment grade } \\
\hline Rating & Long-term ratings & Short-term ratings \\
\hline Aaа & Rated as the highest quality and lowest credit risk. & \multirow{5}{*}{$\begin{array}{l}\text { Prime-1 } \\
\text { Best ability to repay short- } \\
\text { term debt }\end{array}$} \\
\hline Aa1 & \multirow{3}{*}{ Rated as high quality and very low credit risk. } & \\
\hline Aa2 & & \\
\hline Aa3 & & \\
\hline A1 & \multirow{3}{*}{ Rated as upper-medium grade and low credit risk. } & \\
\hline A2 & & \multirow{5}{*}{$\begin{array}{c}\text { Prime-1/Prime-2 } \\
\text { Best ability or high ability } \\
\text { to repay short term debt } \\
\text { Prime-2 } \\
\text { High ability to repay short } \\
\text { term debt } \\
\text { Prime-2/Prime-3 } \\
\text { High ability or acceptable } \\
\text { ability to repay short term } \\
\text { debt } \\
\text { Prime-3 } \\
\text { Acceptable ability to repay } \\
\text { short term debt }\end{array}$} \\
\hline A3 & & \\
\hline Baa1 & \multirow{3}{*}{$\begin{array}{l}\text { Rated as medium grade, with some speculative } \\
\text { elements and moderate credit risk. }\end{array}$} & \\
\hline Baa2 & & \\
\hline Baa3 & & \\
\hline \multicolumn{3}{|c|}{ Speculative grade } \\
\hline Rating & Long-term ratings & Short-term ratings \\
\hline Ba1 & \multirow{3}{*}{$\begin{array}{l}\text { Judged to have speculative elements and a significant } \\
\text { credit risk. }\end{array}$} & \multirow{11}{*}{$\begin{array}{l}\text { Not Prime } \\
\text { Do not fall within any of } \\
\text { the prime categories }\end{array}$} \\
\hline $\mathrm{Ba} 2$ & & \\
\hline $\mathrm{Ba} 3$ & & \\
\hline $\mathrm{B} 1$ & \multirow{3}{*}{ Judged as being speculative and a high credit risk. } & \\
\hline $\mathrm{B} 2$ & & \\
\hline B3 & & \\
\hline Caa1 & \multirow{3}{*}{ Rated as poor quality and very high credit risk. } & \\
\hline Caa2 & & \\
\hline Caa3 & & \\
\hline $\mathrm{Ca}$ & $\begin{array}{l}\text { Judged to be highly speculative and with likelihood of } \\
\text { being near or in default, but some possibility of } \\
\text { recovering principal and interest. }\end{array}$ & \\
\hline $\mathrm{C}$ & $\begin{array}{l}\text { Rated as the lowest quality, usually in default and low } \\
\text { likelihood of recovering principal or interest. }\end{array}$ & \\
\hline
\end{tabular}


Table 2-List of Closed Institutions since 2004**

Table 2. List of closed institutions since AY2004

\begin{tabular}{|c|c|c|c|c|}
\hline Name & $\begin{array}{l}\text { Date Deleted } \\
\text { from IPEDS }\end{array}$ & Carnegie & $\begin{array}{l}\text { Degree } \\
\text { Granting }\end{array}$ & $\begin{array}{c}\text { Undergrad } \\
\text { Serving }\end{array}$ \\
\hline City University-Los Angeles & 2004 & Prior Ranking & Yes & Yes \\
\hline Institute of Paper Science and Technology & 2004 & Prior Ranking & Yes & No \\
\hline $\begin{array}{l}\text { Mercer University in Atlanta } \\
\text { Rosalind Franklin University of Medicine }\end{array}$ & 2004 & Prior Ranking & Yes & No \\
\hline and Science & 2004 & Prior Ranking & Yes & No \\
\hline Barat College & 2005 & BA A\&S & Yes & Yes \\
\hline Christ College of Florida & 2005 & NA & Yes & Yes \\
\hline Eastern Baptist Theological Seminary & 2005 & Religious & Yes & No \\
\hline St Johns Seminary College & 2005 & Religious & Yes & Yes \\
\hline $\begin{array}{l}\text { Atlanta College of Art } \\
\text { Franklin Pierce College-Graduate and }\end{array}$ & 2006 & Art & Yes & Yes \\
\hline Professional Studies & 2006 & MA Medium & Yes & Yes \\
\hline International Institute of the Americas & 2006 & 4yr primary AA & Yes & Yes \\
\hline Metropolitan College & 2006 & Special Focus & Yes & Yes \\
\hline Metropolitan College & 2006 & Special Focus & Yes & Yes \\
\hline St Johns Hospital School of Dietetics & 2006 & NA & No & No \\
\hline Ave Maria College & 2007 & BA A\&S & Yes & Yes \\
\hline Puget Sound Christian College & 2007 & Religious & Yes & Yes \\
\hline $\begin{array}{l}\text { Sheidon Jackson College } \\
\text { Southampton College of Long Island }\end{array}$ & 2007 & BA A\&S & Yes & Yes \\
\hline $\begin{array}{l}\text { University } \\
\text { West Virginia University Hospital }\end{array}$ & 2007 & MA Small & Yes & No \\
\hline Department of Nutrition and Dietetics & 2007 & NA & No & No \\
\hline Academy For Five Element Acupuncture & 2008 & NA & $\mathrm{NA}$ & No \\
\hline $\begin{array}{l}\text { Antioch College } \\
\text { Marymount College of Fordham }\end{array}$ & 2008 & BA A\&S & Yes & Yes \\
\hline University & 2008 & BA Diverse & Yes & Yes \\
\hline $\begin{array}{l}\text { New College of California } \\
\text { New York Institute of Technology-Central }\end{array}$ & 2008 & MA Medium & Yes & Yes \\
\hline Islip & 2008 & BA Diverse & Yes & Yes \\
\hline $\begin{array}{l}\text { Pillsbury Baptist Bible College } \\
\text { St Vincent Catholic Medical Center New }\end{array}$ & 2008 & Religious & Yes & Yes \\
\hline York-Brooklyn and Queens & 2008 & NA & No & Yes \\
\hline Vennard College & 2008 & Religious & Yes & Yes \\
\hline Weston Jesuit School of Theology & 2008 & Religious & Yes & No \\
\hline Baltimore Hebrew University Inc & 2009 & Special Focus & Yes & Yes \\
\hline Beacon University & 2009 & Religious & Yes & Yes \\
\hline Cascade College & 2009 & BA A\&S & Yes & Yes \\
\hline College of Santa $\mathrm{Fe}$ at Albuquerque & 2009 & NA & NA & Yes \\
\hline Magnolia Bible College & 2009 & Religious & Yes & Yes \\
\hline Rabbinical Seminary of Adas Yereim & 2009 & Religious & Yes & Yes \\
\hline
\end{tabular}


Table 2 (continued)-List of closed institutions since $2004 * *$

Table 2. List of closed institutions since AY2004 (continued)

\begin{tabular}{|c|c|c|c|c|}
\hline Name & $\begin{array}{l}\text { Date Deleted } \\
\text { from IPEDS }\end{array}$ & Carnegie & $\begin{array}{l}\text { Degree } \\
\text { Granting }\end{array}$ & $\begin{array}{l}\text { Undergrad } \\
\text { Serving }\end{array}$ \\
\hline Salem Bible College & 2009 & NA & Yes & Yes \\
\hline Southeastern University & 2009 & MA Medium & Yes & Yes \\
\hline Taylor University Fort Wayne & 2009 & BA. Diverse & Yes & Yes \\
\hline Taylor University Graduate School & 2009 & NA & NA & No \\
\hline Temple Baptist Seminary & 2009 & Religious & Yes & Yes \\
\hline Woodbury Institute at Champlain College & 2009 & BA. Diverse & Yes & Yes \\
\hline Dana College & 2010 & BA Diverse & Yes & Yes \\
\hline Jones College-Miami Campus & 2010 & Business & Yes & Yes \\
\hline Midwest University & 2010 & Religious & Yes & Yes \\
\hline Sage College of Albany & 2010 & MA Large & Yes & Yes \\
\hline Southern Catholic College & 2010 & BA A\&S & $\mathrm{NA}$ & Yes \\
\hline $\begin{array}{l}\text { Southern New England School of Law } \\
\text { UPMC Presbyterian Shadyside Dietetic }\end{array}$ & 2010 & Law & Yes & No \\
\hline Internship & 2010 & NA & No & No \\
\hline $\begin{array}{l}\text { Wesley College } \\
\text { Ashland University Dwight Schar College }\end{array}$ & 2010 & $\begin{array}{l}\text { Religious } \\
\text { Health }\end{array}$ & Yes & Yes \\
\hline of Nursing & 2011 & Professionals & Yes & Yes \\
\hline Baker College Corporate Services & 2011 & BA Diverse & Yes & Yes \\
\hline Baltimore International College & 2011 & Special Focus & Yes & Yes \\
\hline $\begin{array}{l}\text { Bethany University } \\
\text { Cleveland Chiropractic College of Los }\end{array}$ & 2011 & $\begin{array}{l}\text { BA Diverse } \\
\text { Health }\end{array}$ & Yes & Yes \\
\hline $\begin{array}{l}\text { Angeles } \\
\text { Hebrew Union College-lewish Institute of }\end{array}$ & 2011 & Professionals & Yes & Yes \\
\hline $\begin{array}{l}\text { Religion-Cincinnati } \\
\text { Hebrew Union College-Jewish Institute of }\end{array}$ & 2011 & Religious & Yes & No \\
\hline $\begin{array}{l}\text { Religion-Los Angeles } \\
\text { McLeod Regional Medical Center School }\end{array}$ & 2011 & Religious & Yes & No \\
\hline $\begin{array}{l}\text { of Medical Technology } \\
\text { Trine University-South Bend Regional }\end{array}$ & 2011 & $\mathrm{NA}$ & No & No \\
\hline Campus & 2011 & BA Diverse & Yes & Yes \\
\hline
\end{tabular}

This approach allowed us to examine the differences between institutions that closed and institutions that remained open rather than looking at a single institution over time. The incommon differences revealed through data analysis provide the basis for the at-risk indicators we propose for consideration by college and university administrators of the small enrollment private institution.

\section{Findings}

As seen in Table 2, private institution closures are dominated by two types of institutions: religious institutions and those not classified by the Carnegie Commission (typically non-degree granting institutions). These 14 religious and 10 unclassified institutions make up over $42 \%$ of closures during this time. In addition, small bachelor's granting institutions (those classified with a focus on arts and sciences or diverse fields) contribute another nearly $25 \%$.

** Lyken-Segosebe, Dawn, and Justin C. Shepherd. "Knocking at the College Door." WICHE. Tennessee Independent Colleges and Universities Association (TICUA), July 2013. Web. 12 May 2014. 


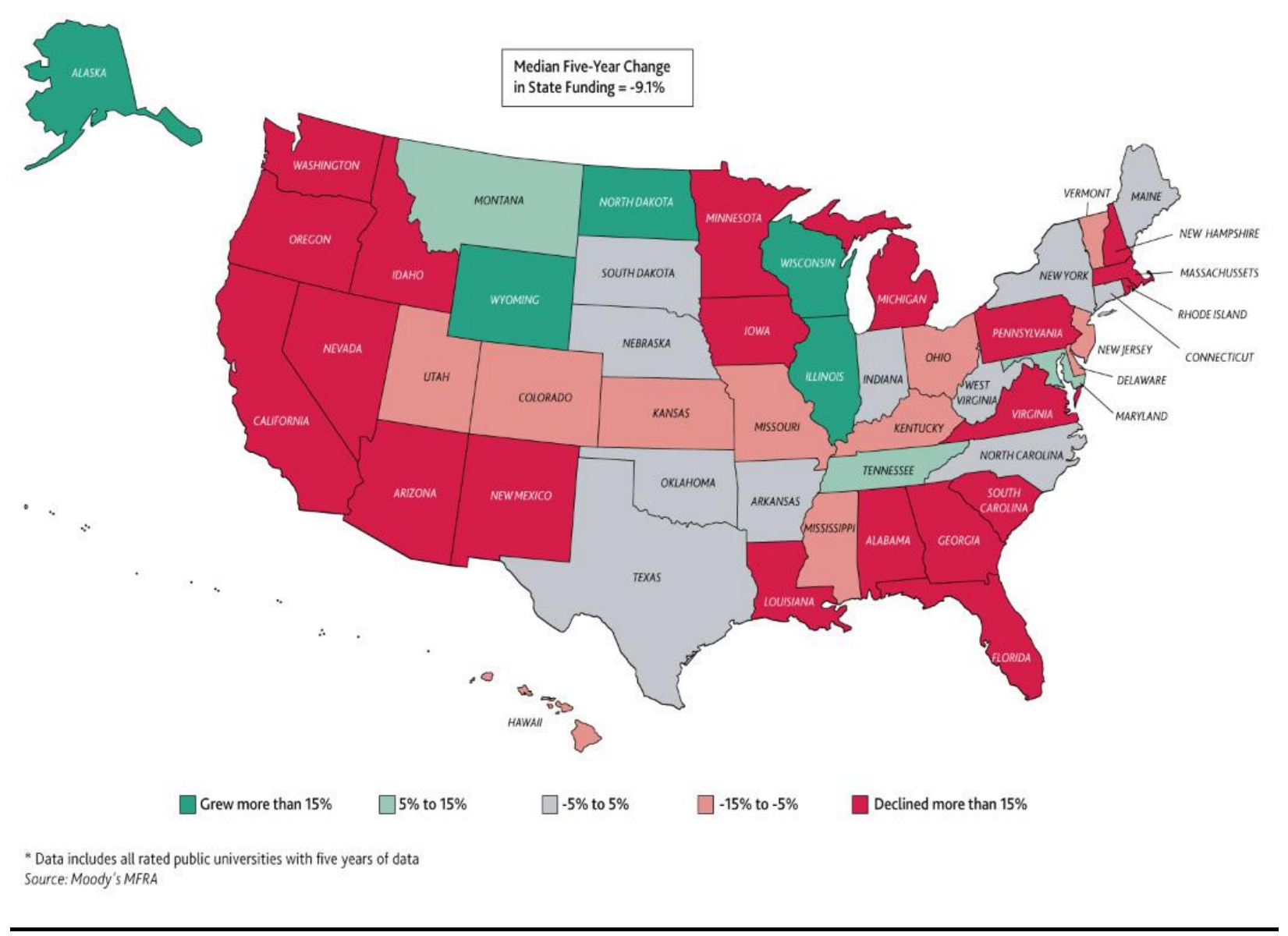

Figure 1: Approximately $60 \%$ of states cut state funding since 2008* Shading reflects five-year change in gross state funding

* Bogarty, E., Kedem, K., Behr, E., Fitzgerald, S., \& Smith, K. M. (2013, November 25). 2014 Outlook - US higher education, not-for-profits and independent schools (Rep. No. 160659). 
Total spending per student (Figures are constant 2012 dollars)

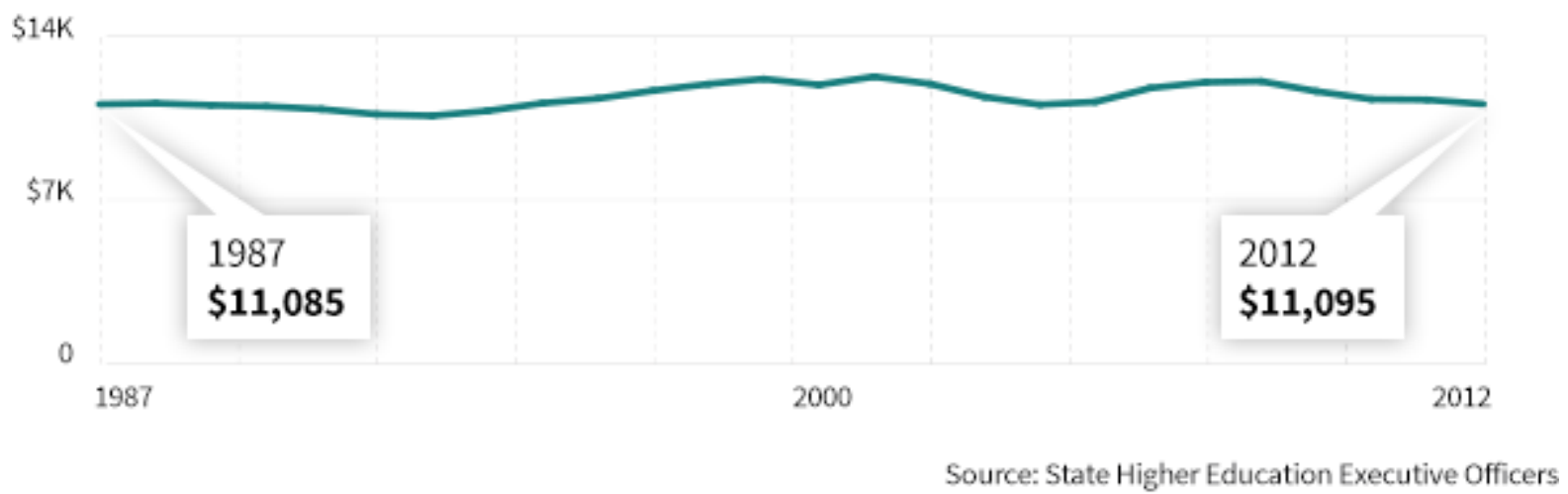

Figure 2: State spending per FTE student 


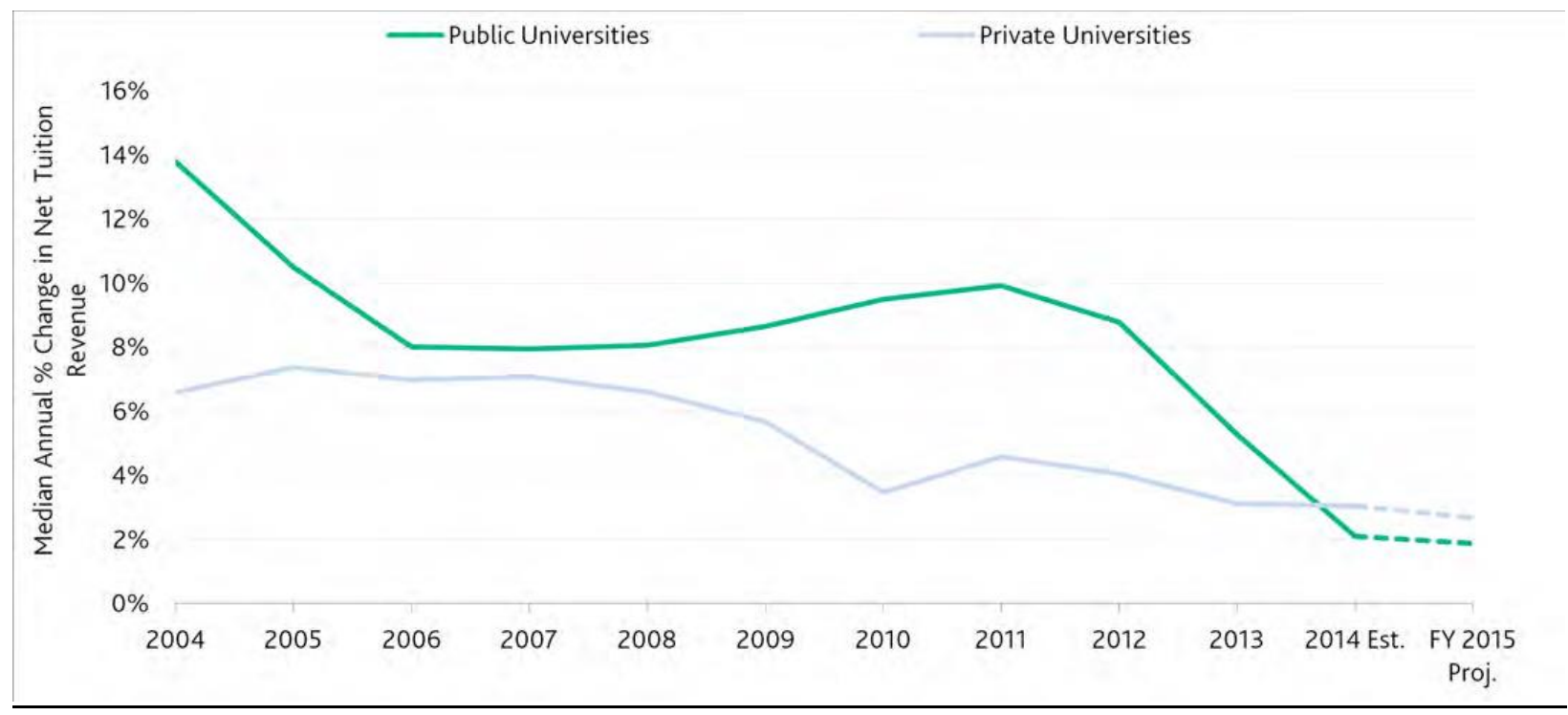

Figure 3-Pricing Power Continues to Erode for Public and Private Universities* (2015 outlook)

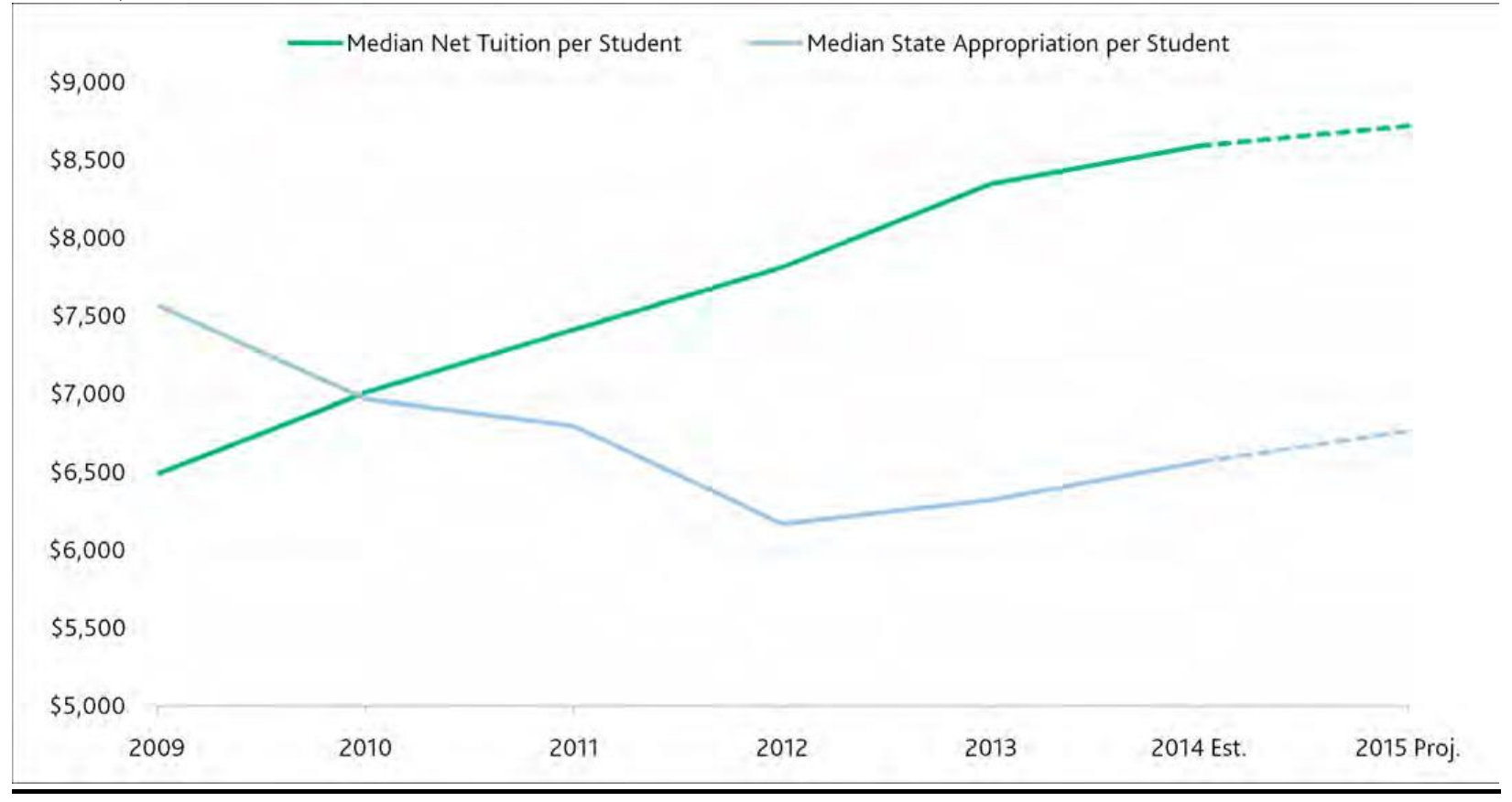

Figure 4-Growth of Net Tuition per Student Eclipses State Appropriations at Public Universities* (2015 outlook)

* Tuby, K., Fitzgerald, S., Kedem, K., Behr, E., \& Smith, K. (2014, December 01). 2015 outlook -- US higher education: Slow tuition revenue growth supports negative outlook (Rep.). 


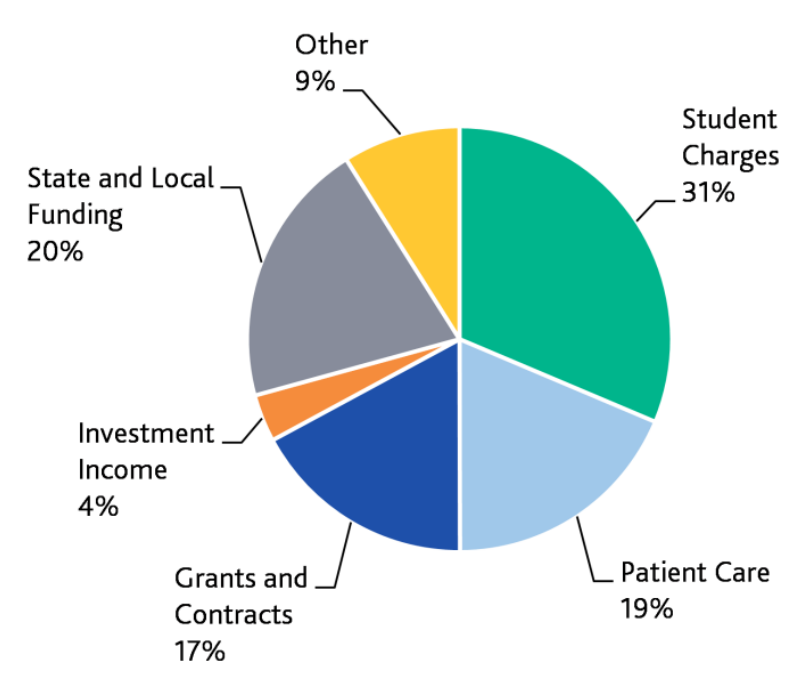

Figure 5- Sector-Wide Public Revenues are Diversified (\% Operating Revenuesprojected FY 2016)*

Public Universities Derive an Aggregate 20\% of Funding from their States

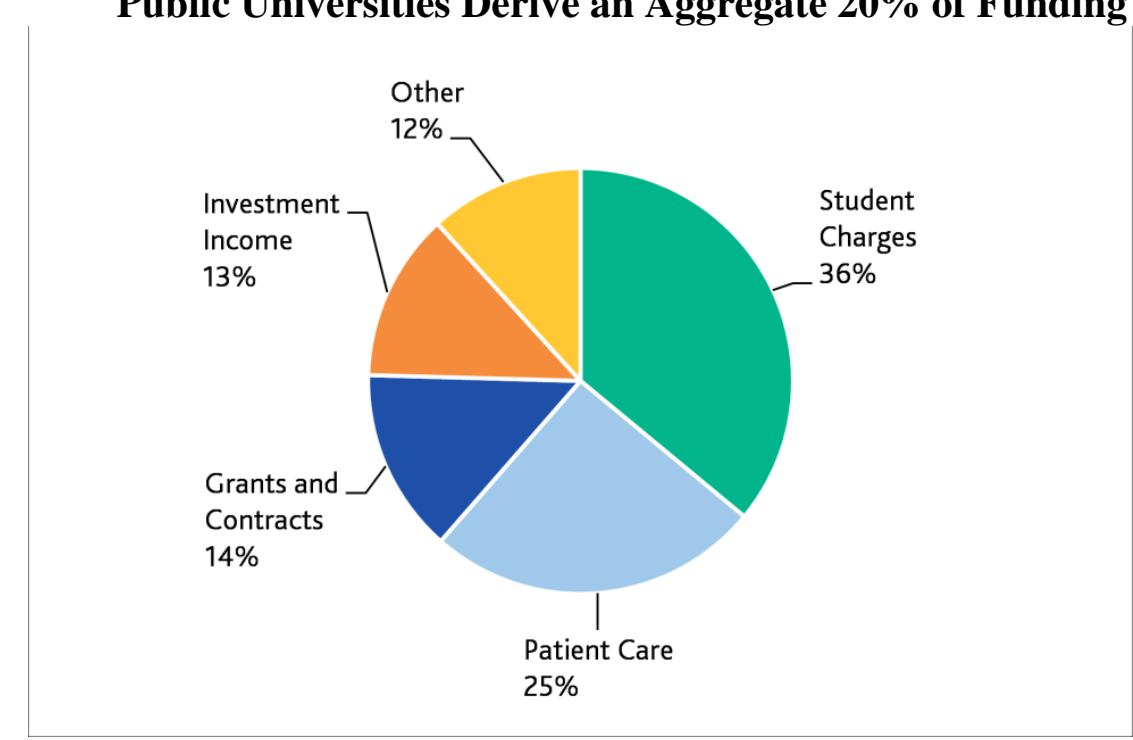

Figure 6- Sector-Wide Private Revenues are Diversified (\% Operating Revenuesprojected FY 2016)*

Private Universities Have a Higher Exposure to Investment Income

*Bogarty, Eva. "Moody's: Modest Revenue Growth Supports Stable Outlook for US Higher Education in 2016." Moodys.com. Moody's Investors Service, 02 Dec. 2015. Web. 05 Dec. 2015. 


\section{The College Wage Premium}

Hourly wages by education for all genders, in 2012 dollars

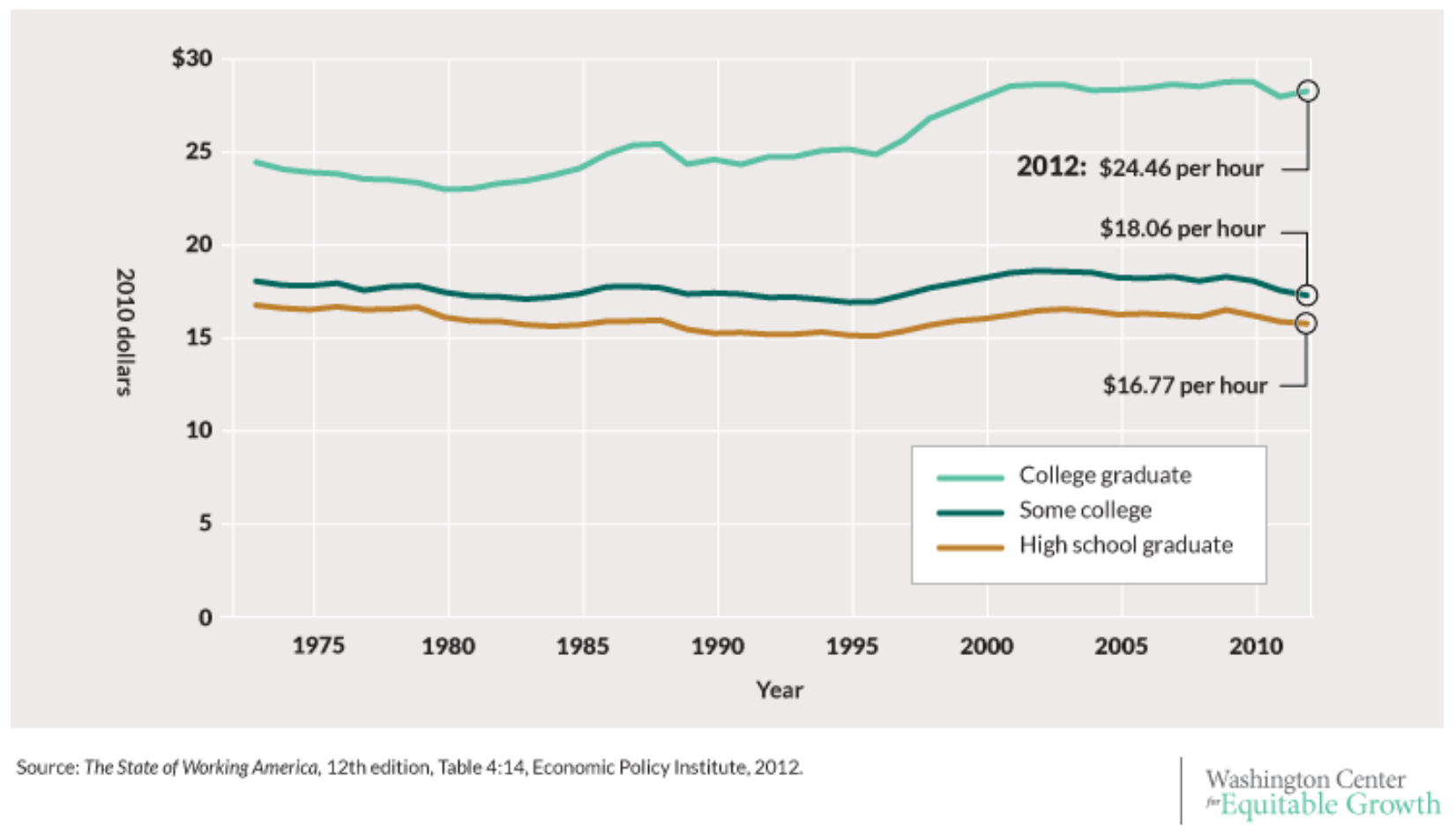

Figure 7-College Wage Premium 


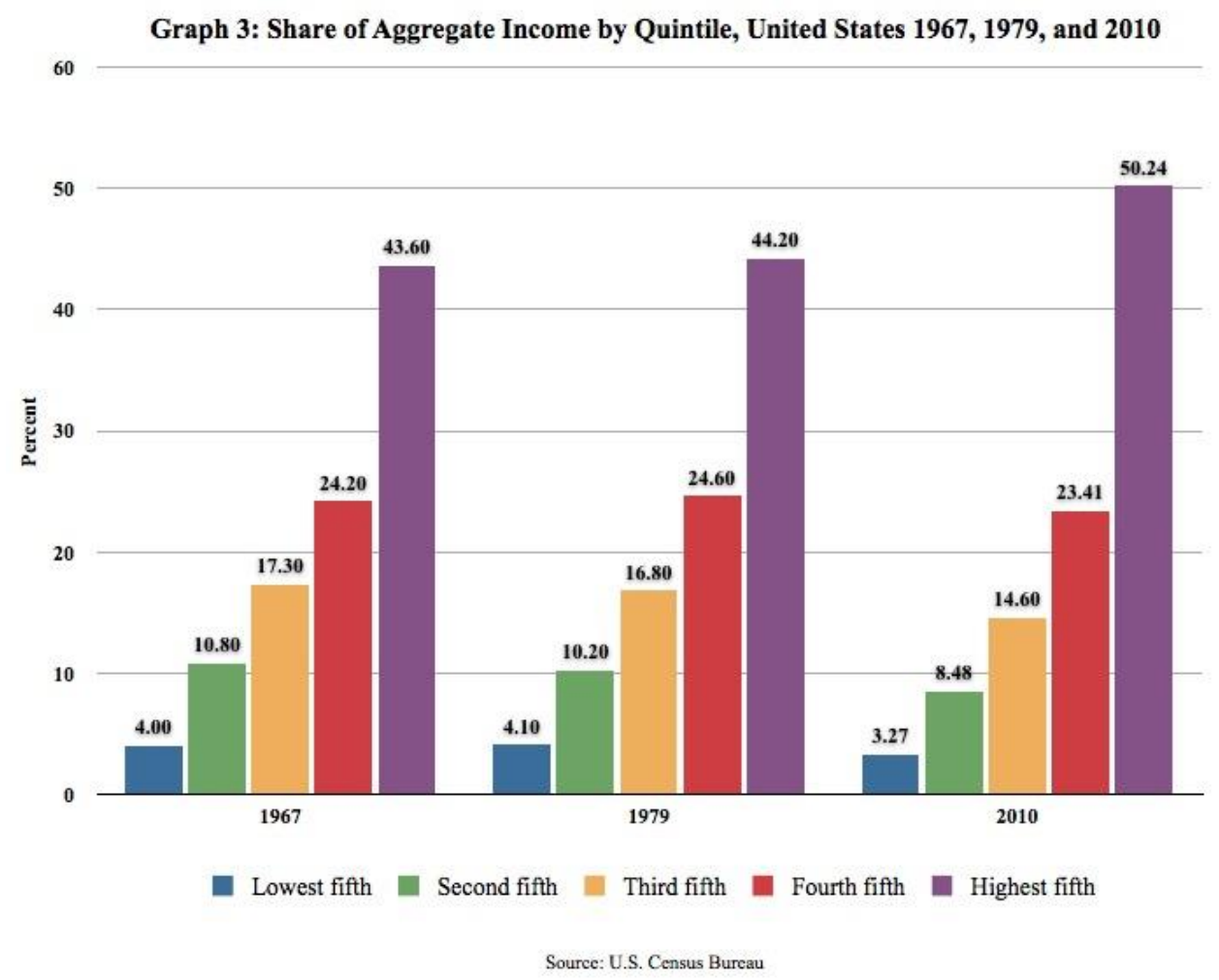

Figure 8-Aggregate Income By Quintile 


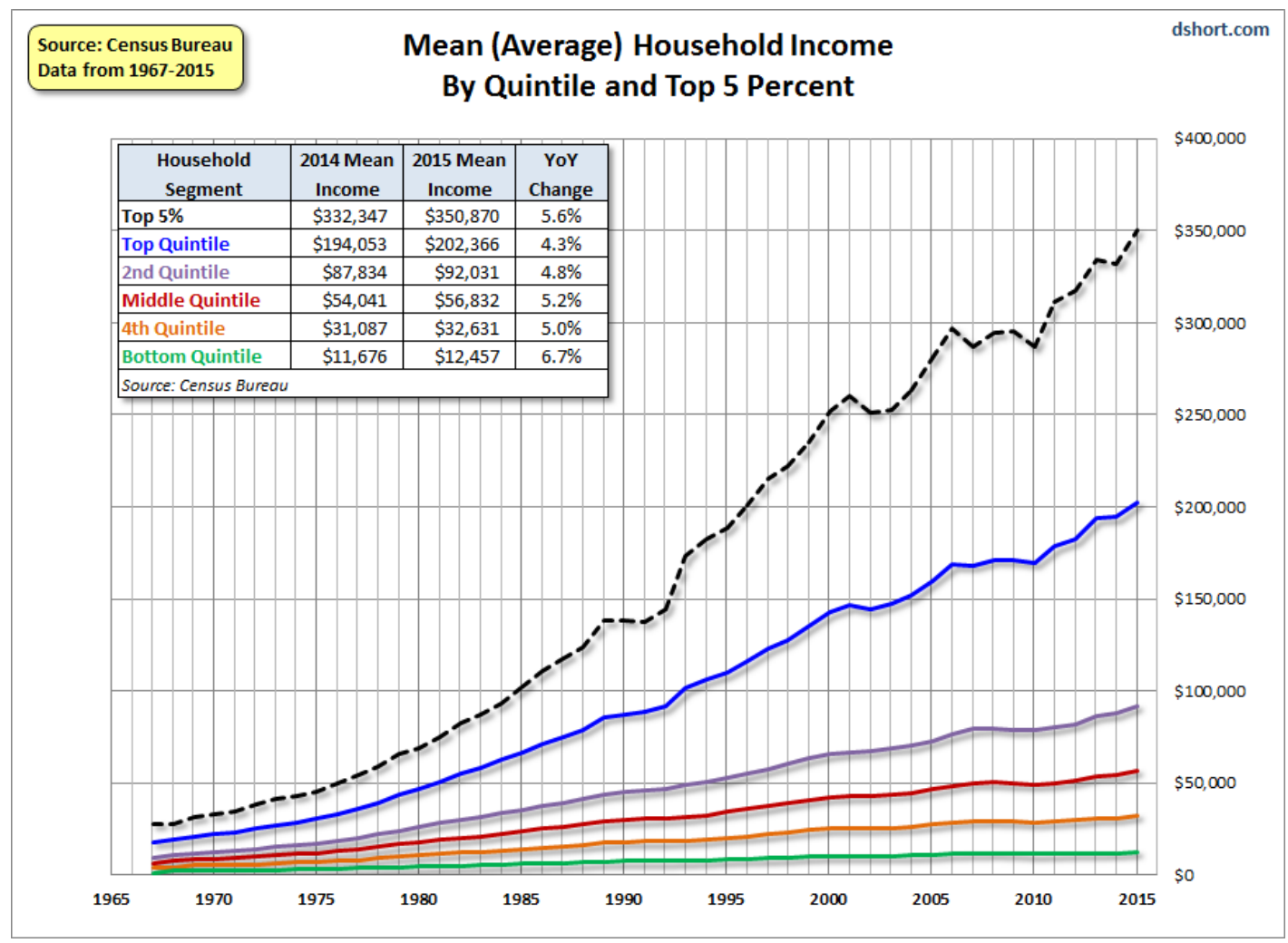

Figure 9-Income Distribution By Quintile

Widening of the Income Gap 1967-2015 


\section{References}

Archibald, R. B., \& Feldman, D. H. (2011). Why does college cost so much? Oxford: Oxford University Press.

Bassis, M. (2015, July). A primer on the transformation of higher education in America [Scholarly project]. In Learning Outcome Assessments.org. Retrieved from http://www.learningoutcomesassessment.org/documents/BassisPrimer.pdf

Baum, S., \& Payea, K. (2013). Trends in student aid 2013 (Publication). College Board. Retrieved http://trends.collegeboard.org/sites/default/files/student-aid-2013-fullreport.pdf

Baum, S., Kurose, C., \& McPherson, M. (2013). An overview of American higher education. The Future of Children. Retrieved from http://www.princeton.edu/futureofchildren/publications/docs/23_01_02.pdf

Baum, S., Ma, J., Pender, M., \& Bell, D. (2015). Trends in student aid 2015 (Publication). College Board. Retrieved http://trends.collegeboard.org/sites/default/files/trends-studentaid-web-final-508-2.pdf

Baumol, W. J., \& Bowen, W. G. (1966). Performing arts: The economic dilemma: A study of problems common to theater, opera, music and dance; by w.j. baumol and w.g. bowen. New York: Twentieth Century Fund.

Bogarty, E., \& Smith, K. (2015, July 20). US higher education: Sector stabilizes with modest revenue growth in challenging environment (Rep.). Retrieved https://www.moodys.com/research/Moodys-US-higher-education-outlook-revised-tostable-as-revenues--PR_330530 
Bogarty, E., Behr, E., Kedem, S., \& Nelson, J. (2013, January 16). US higher education outlook negative in 2013 (Rep. No. 148880). Retrieved http://www.marquette.edu/budget/documents/USHigherEducationOutlookNegativein201 3.pdf

Bogarty, E., Kedem, K., Behr, E., Fitzgerald, S., \& Smith, K. M. (2013, November 25). 2014 Outlook - US higher education, not-for-profits and independent schools (Rep. No. 160659). Retrieved https://www.moodys.com/research/2014-Outlook-US-HigherEducation-Not-for-Profits-and-Independent--PBM_PBM160659.

Bowen, W. G., \& McPherson, M. S. (2016). Lesson Plan: An agenda for change in American higher education. Princeton, NJ: Princeton University Press.

Bowen, W. G., \& Tobin, E. M. (2015). Locus of authority: The evolution of faculty roles in the governance of higher education. Princeton: Princeton University Press.

Bowen, W. G. (1976). The economics of Princeton in the 1970s: Some worrisome implications of trying to make do with less. Report of the President. Retrieved from http://findingaids.princeton.edu/collections/AC168/c00004

Bowen, W. G. (2015). Higher education in the digital age. Princeton, NJ: Princeton Univ Press. Cappelli, P. (2012). Why good people can't get jobs: The skills gap and what companies can do about it. Philadelphia: Wharton Digital Press.

Carey, K. (2016). The end of college: Creating the future of learning and the university of everywhere. New York: Riverhead Books.

Chetty, R., Friedman, J. N., Saez, E., N., Turner, \& Yagan, D. (2017, January). Mobility report cards: The role of colleges in intergenerational mobility (Publication). Retrieved http://www.equality-of-opportunity.org/papers/coll_mrc_paper.pdf 
Chetty, R., Gurski, D., Mell, M., Hendren, N., Manduca, R., \& Narang, J. (2016, December). The fading American dream: Trends in absolute income mobility since 1940 (Rep. No. 22910). Retrieved http://www.nber.org/papers/w22910

Christensen, C. M., \& Eyring, H. J. (2011). The innovative university changing the DNA of higher education from the inside out. San Francisco: Jossey-Bass.

Cole, J. R. (2009). The great American university: Its rise to preeminence, its indispensable national role, why it must be protected. New York: Public Affairs.

Collins, C., \& Smith, K. (2016, July 06). Moody's: US state budgets offer mixed results for public universities (Rep.). Retrieved https://www.moodys.com/research/Moodys-USstate-budgets-offer-mixed-results-for-public-universities--PR_351762

Congress Approves FY 2014 Omnibus Funding Bill Increasing Funding for NIH and Other Federal Public Health Programs (Rep.). (2014, January 23). American Society of Hematology. Retrieved http://www.hematology.org/Advocacy/PolicyNews/2014/2578.aspx

Craig, R. (2015). College disrupted: The great unbundling of higher education. New York: Palgrave Macmillan Trade.

Creswell, J. W. (2014). Educational research: Planning, conducting, and evaluating quantitative and qualitative research. Los Angeles, CA: Sage Publications.

Denneen, J., \& Dretler, T. (2012). The financially sustainable university (Rep.). Bain \& Company.

Fitzgerald, S., \& Smith, K. (2016, February 23). Moody's: Global changes in economy, technology, and finance transforming environment for higher education (Rep.). Retrieved 
https://www.moodys.com/research/Moodys-Global-changes-in-economy-technologyand-finance-transforming-environment--PR_344440

Fitzgerald, S., E., Behr, Tuby, K., \& Smith, K. M. (2015, December 02). US higher education: 2016 outlook - Moderate revenue growth supports sector stability (Rep.). Retrieved https://www.moodys.com/research/Moodys-Modest-revenue-growth-supports-stableoutlook-for-US-higher--PR_340333

Gephardt, D., \& Smith, K. (2015, September 25). Moody's: US higher education outlook revised to stable as revenues stabilize (Rep.). Retrieved https://www.moodys.com/research/Moodys-Small-but-notable-rise-expected-in-closuresmergers-for--PR_335314

Gephardt, D., \& Ortiz, E. (2014, July 14). Moody's: Negative outlook continues for US higher education, although signs of stability are emerging (Rep.). Retrieved https://www.moodys.com/research/Moodys-Negative-outlook-continues-for-US-highereducation-although-s...

Goldin, C. D., \& Katz, L. F. (2008). The race between education and technology. Cambridge, MA: Belknap Press of the Harvard University Press.

Goldstein, M., \& Otte, G. (2016). Change we must: Deciding the future of higher education. New York: Rosettabooks.

Hebel, S. (2014, March 02). From public good to private good: How higher education got to a tipping point. Retrieved from http://chronicle.com/article/From-Public-Good-toPrivate/145061

Hill, C. B. (2013, February 15). Response to Moody's outlook on higher education. Financial Times. 
Hunter, J. E., \& Hunter, R. F. (1984). Validity and utility of alternative predictors of job performance. Psychological Bulletin 96. Retrieved from https://www.scribd.com/document/134261505/Hunter-Hunter-1984-Validity-and-Utilityof-Alternative-Predictors-of-Job-Performance

Jacobs, P. (2015, March 12). Here's how many colleges have closed in the past 25 years. Retrieved from http://www.businessinsider.com/college-closings-chart-2015-3

Jason, G. (2016, June 13). Moore's law versus the law of more — The James G. Martin Center for Academic Renewal. Retrieved from http://www.jamesgmartin.center/2012/08/moores-law-versus-the-law-of-more/

Kaiser, J. (2014, December 10). Within NIH's flat 2015 budget, a few favorites. Science. Retrieved from http://news.sciencemag.org/funding/2014/12/within-nih-s-flat-2015budget-few-favorites

Kedem, K., \& Yake, M. (2015, November 23). Rating methodology: Global higher education (Rep.). Retrieved https://www.moodys.com/

Kedem, K. (2011, August 26). Rating methodology: U.S. not-for-profit private and public higher education (Rep.). Retrieved http://www.nebhe.org/info/pdf/tdbank_breakfast/093011/KimTuby_MoodysRatingMetho dology_USHigherEducation_2011.pdf

Kerr, C. (2001). The Uses of the University (5th ed.). Cambridge: Harvard University Press.

Lindstrom, S. (2014, February 10). 2014-2015 Pell grant amount [Web log post]. Retrieved from http://www.estudentloan.com/blog/2014-2015-pell-grant-amount 
Lyken-Segosebe, D., \& Shepherd, J. C. (2013). Learning from closed institutions: Indicators of risk for small private colleges and universities (Rep.). Nashville, TN: Vanderbilt University.

Menon, N., Teng, P. Y., Asad, A., \& Pasupathy, S. (2016). Rethinking k-20 education (Rep.). Retrieved https://www.atkearney.com/documents/10192/9654505/Rethinking+K20+Education.pdf/ac6ba1bb-bf76-44a3-b20f-a14328f3316b

Mervis, J. (2014, December 10). NSF's 2015 budget: A small increase and a big pat on the back. Science. Retrieved from http://news.sciencemag.org/funding/2014/12/nsf-s-2015-budgetsmall-increase-and-big-pat-back

National Science Foundation. (2016). FY 2016 NSF Budget Request to Congress. Retrieved from https://www.nsf.gov/about/budget/fy2016/pdf/62_fy2016.pdf

Ortiz, E., \& Fitzgerald, S. (2015, November 19). Moody's: Low net tuition growth will persist for US private and public universities (Rep.). Retrieved https://www.moodys.com/research/Moodys-Low-net-tuition-growth-will-persist-for-USprivate--PR_339457

Ortiz, E., \& Smith, K. (2016, November 29). Moody's: Tuition revenue growth for US private universities remains steady, but public colleges lagging (Rep.). Retrieved https://www.moodys.com/research/Moodys-Tuition-revenue-growth-for-US-privateuniversities-remains-steady--PR_358719

Ortiz, E., Fitzgerald, S., Behr, E., Tuby, K., \& Smith, K. M. (2016, December 07). Higher Education -- US: 2017 Outlook - Stable with Clouds Forming on Horizon (Rep.). Retrieved https://www.moodys.com/research/Moodys-US-not-for-project-highereducations-diverse-revenue-sources--PR_359152 
Picciano, A. G. (2017). Online education policy and practice: The past, present, and future of the digital university. New York; London: Routledge.

Piketty, T., Saez, E., \& Zucman, G. (2016, December 2). Distributional national accounts: Methods and estimates for the United States (Rep.). Retrieved http://www.nber.org/papers/w22945

Prescott, B. T. (2012, November 30). Knocking at the college door: Projections of high school graduates. Retrieved from https://eric.ed.gov/?id=ED540129

Rivard, R. (2013). Moody's: University downgrades continue. Inside Higher Ed. Retrieved from http://www.insidehighered.com/quicktakes/2013/10/30/moodys-university-downgradescontinue\#sthash.WgmSxq2i.dpbs

Rudolph, F., \& Thelin, J. R. (1990). The American college and university: A history. Athens: University of Georgia Press.

Spaulding, S., Hirsch, L., Kauder, R., Desmond, T., \& Duitch, S. (2012). Jobs for New York's future: Report of the city university of New York jobs taskforce 2012 (Rep.). Retrieved https://www.cuny.edu/employment/Jobs-Task-Force.pdf

Stratford, M. (2014). Accord on appropriations. Inside Higher Ed. Retrieved from http://www.insidehighered.com/news/2014/01/14/budget-negotiators-reach-deal-wouldincrease-nih-spending-pell-grant- award\#sthash.L91AMWo0.dpbs

Sykes, C. J. (2016). Fail U.: The false promise of higher education. New York: St. Martin's Press.

Tuby, K., Fitzgerald, S., Kedem, K., Behr, E., \& Smith, K. (2014, December 01). 2015 outlook -US higher education: Slow tuition revenue growth supports negative outlook (Rep.). 
Retrieved https://www.moodys.com/research/Moodys-Slow-tuition-growth-supportscontinued-negative-outlook-for-US--PR_314106

United States, The Medicaid and CHIP Payment and Access Commission. (n.d.). Retrieved from https://www.macpac.gov/subtopic/medicaids-share-of-state-budgets/.

U.S. Comptroller General, The Medicaid and CHIP Payment and Access Commission. (2017). Retrieved from https:/www.macpac.gov/subtopic/medicaids-share-of-state-budgets/

U.S. Department of Education, Federal Student Aid. (2017, March 13). Federal Pell Grants. Retrieved March 20, 2017, from https://studentaid.ed.gov/types/grants-scholarships/pell

U.S. Department of Education, National Center for Education Statistics. (2016, February). Undergraduate Enrollment. Retrieved March 9, 2017, from table 303.70 https://nces.ed.gov/programs/coe/indicator_cha.asp

U.S. Department of Health and Human Services, National Institutes of Health. (2017, March 06). What we do-budget-NIH Appropriations. Retrieved from https://www.nih.gov/aboutnih/what-we-do/budget

Zemsky, R. (2013). Checklist for change: Making American higher education a sustainable enterprise. New Brunswick, NJ: Rutgers University Press. 